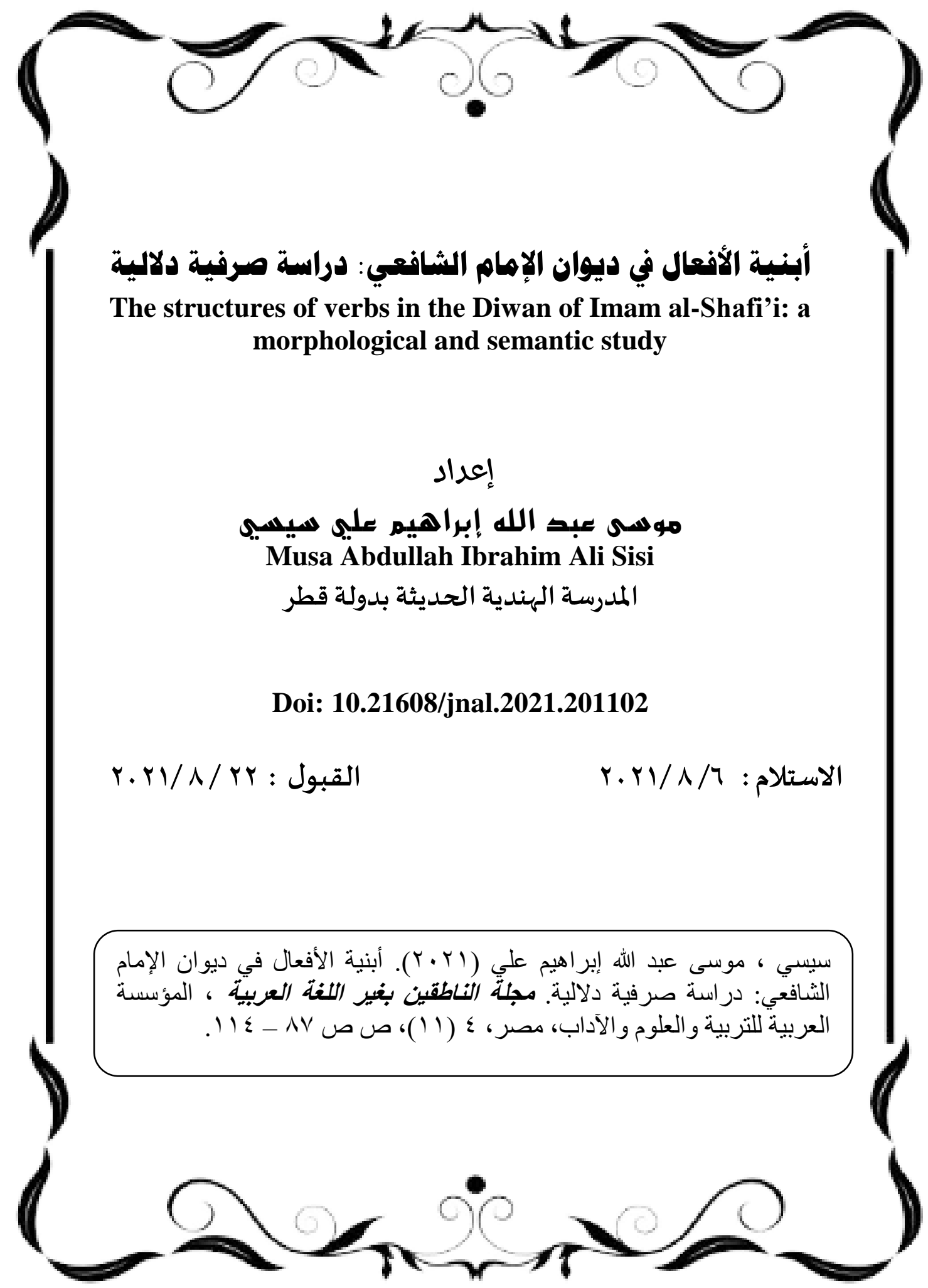




\section{أبنية الأفعال في ديوان الإمام الثـافعي: دراسة صرفية دلالية}

يمتاز أشعار الإمام الثافعي بالبساطة والواقعية كما يمتاز بكثرة الحكم

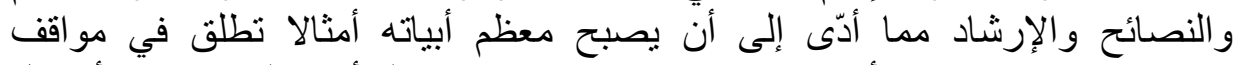

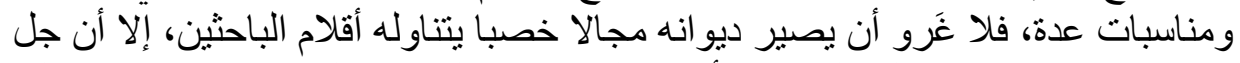

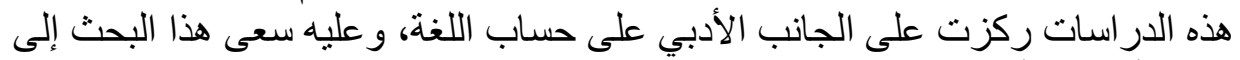

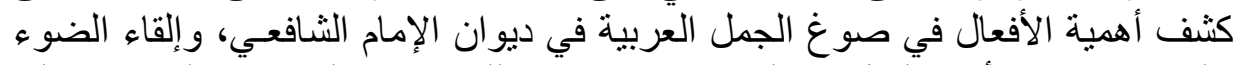

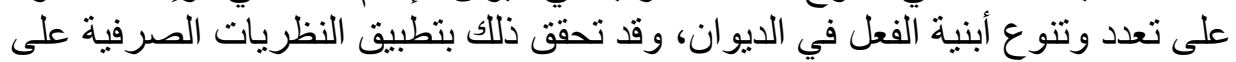

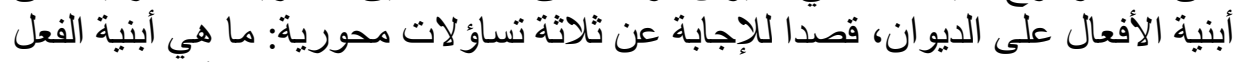

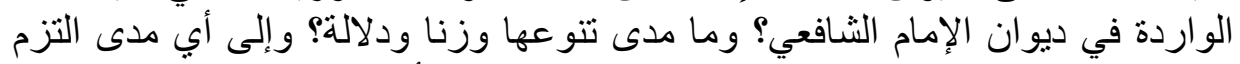

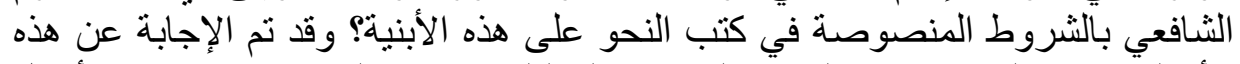

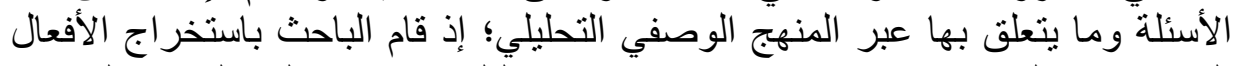

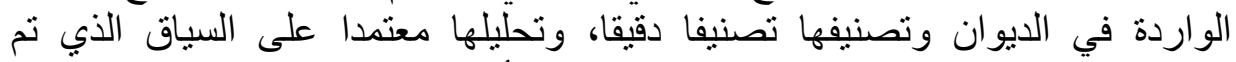

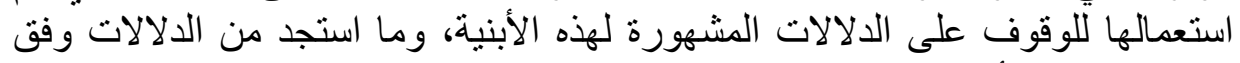

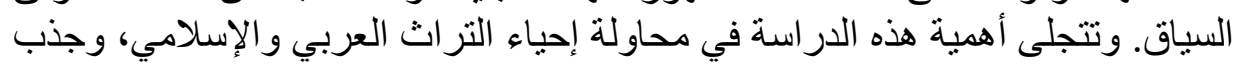

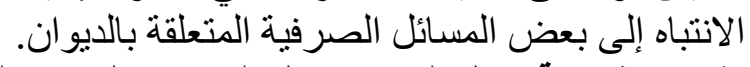

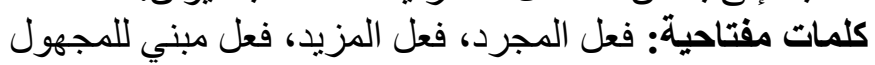

\section{ABSTRACT}

This study seeks to investigate verb structure in Imam Shafi' is poetic works. It is a theme-oriented collection of poems attributed to him which deals with specific themes in a general style. The choice for this literary piece is informed by its exhibition of deliberate and extravagant display of rhetorical devices, as well as easy accessibility of its content relative to other classical poetic works, which could barely be appreciated without an advanced Arabic dictionary. This collection of poems however is made up of nineteen different parts under each of which are group of assemblies with varying themes. While most of the themes are inter-locked, a few others are different. One thing is certain though, beneath each assembly, one will discover a strong religious tone, a sound moral lesson, as well as a good pearl of wisdom replete with 
vast socio-cultural knowledge and rich linguistics material worthy of attention. This study on the other hand sought to highlight how the various forms of Arabic verb structure, mainly three consonantal root and four consonantal roots, and their related extensions contribute to meaning formation in this literary piece. This was accomplished jointly via a descriptive linguistic analysis $\&$ text interpretation.

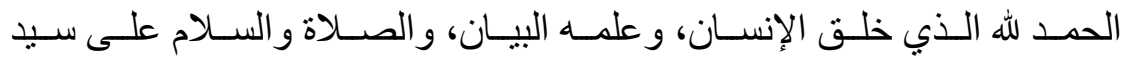

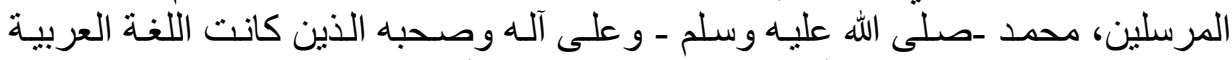

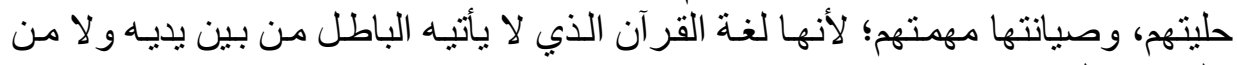

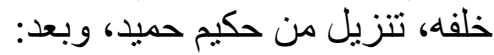
إن للنصوص الأدبية التر اثية مكانة عالية في الحفاظ على اللغة العربية وتقدمها،

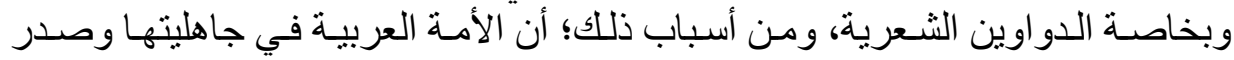

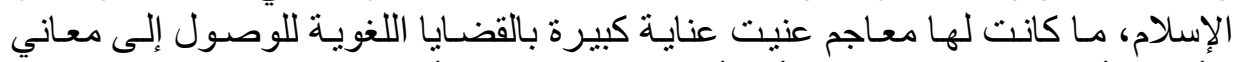

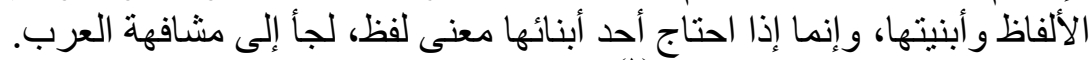

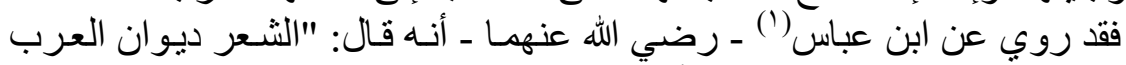

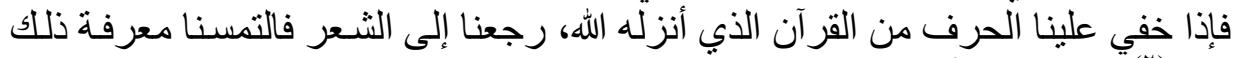

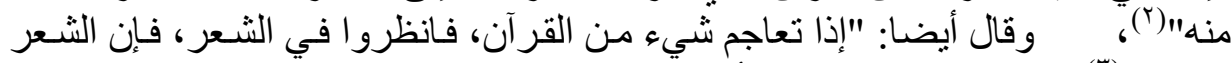

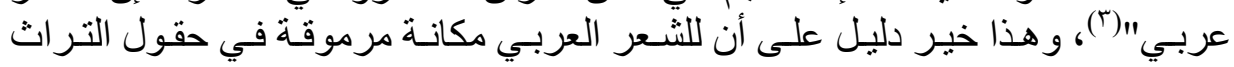

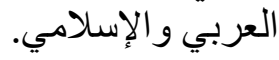

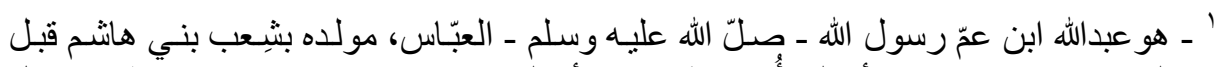

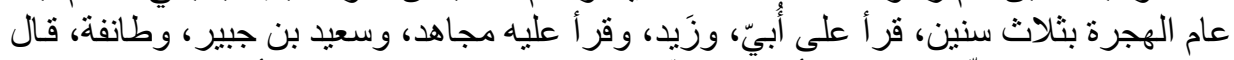

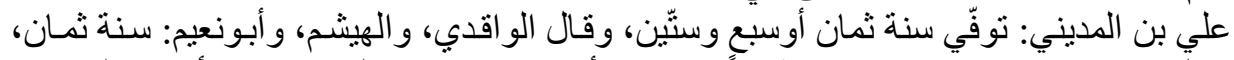

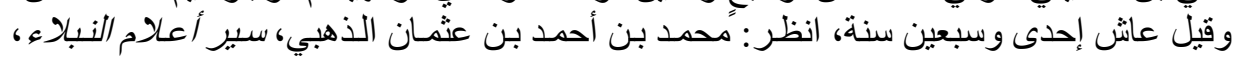

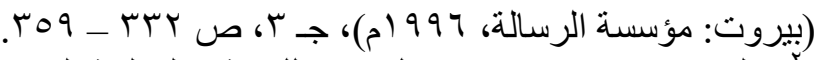

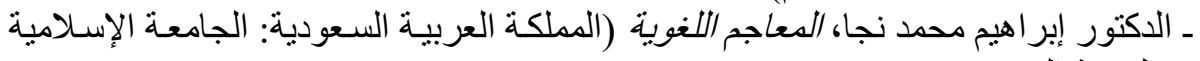

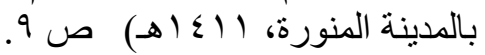




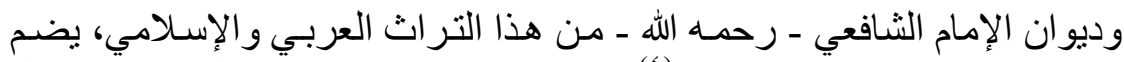

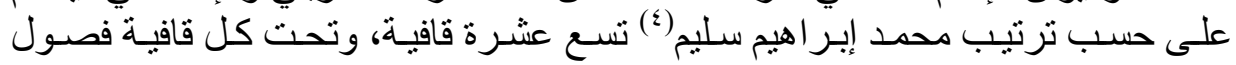

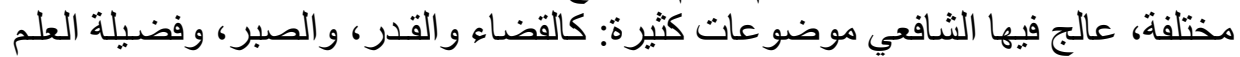

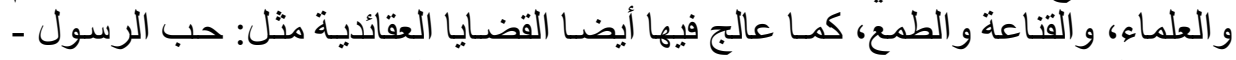

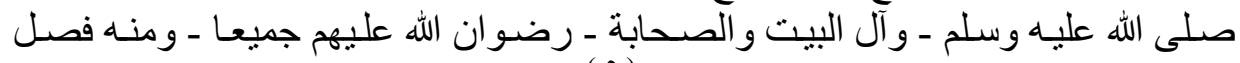

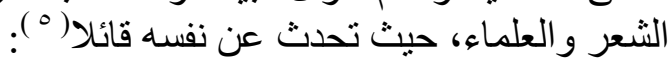

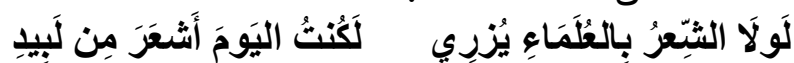

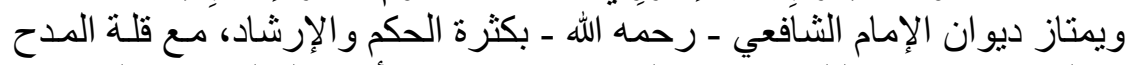

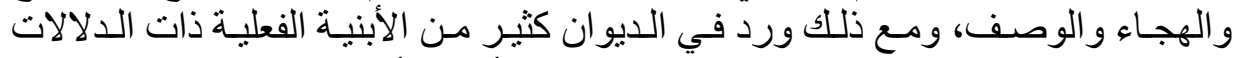

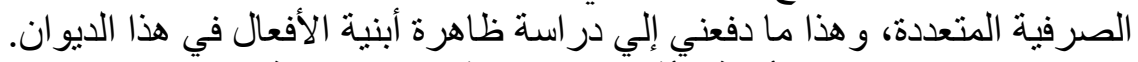

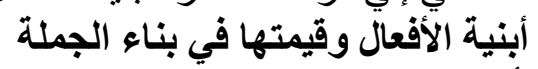

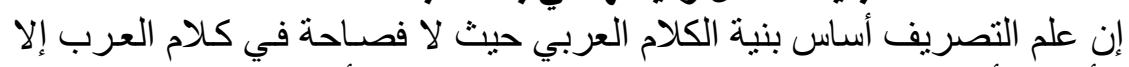

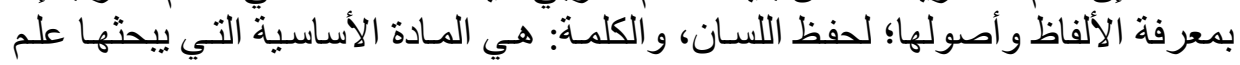

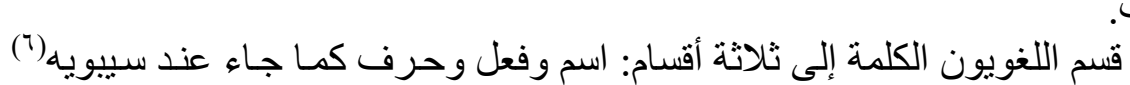
الصرف.

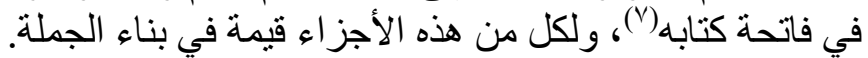

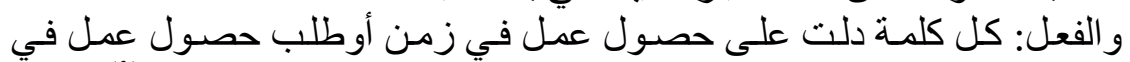

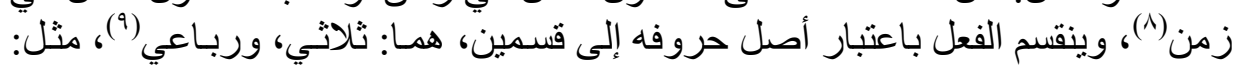

؛ ـ محقق كتاب: الجوهر النفيس في شعر الإمام محمد بن إدريس، وهو الكتاب الذي اعتمدت

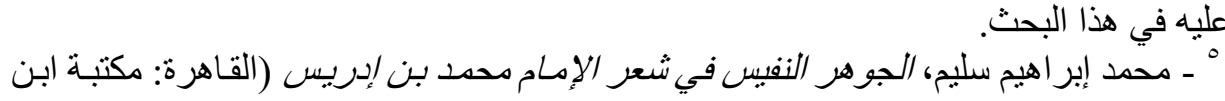

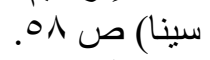

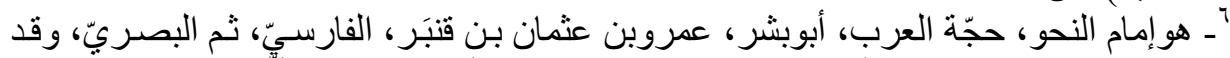

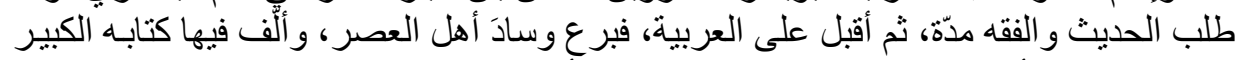

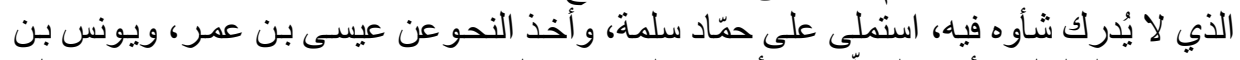

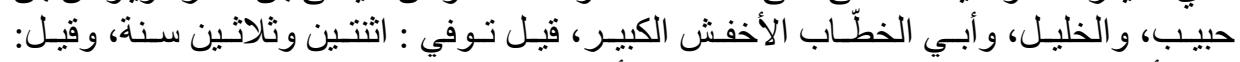

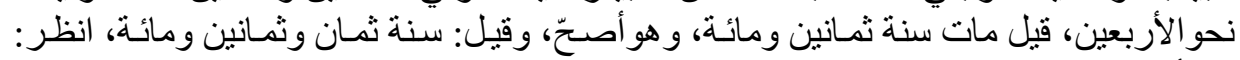

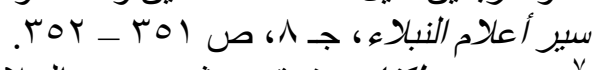

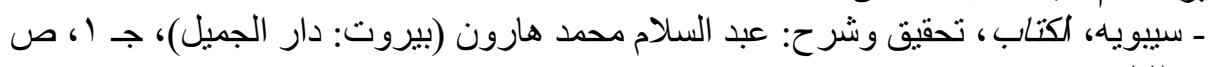
^ - - المرجع نفسها.

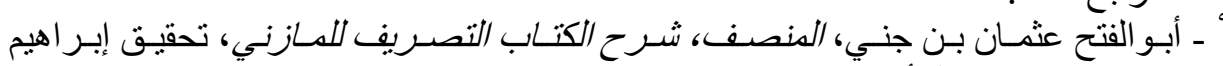

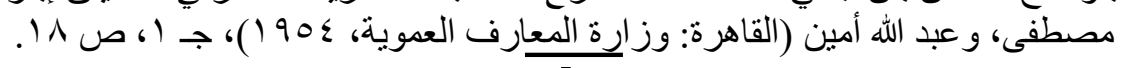




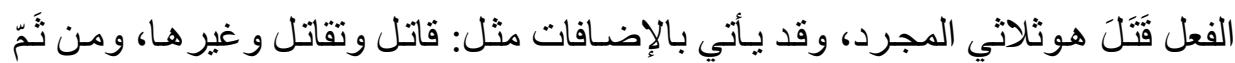

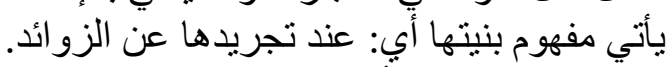

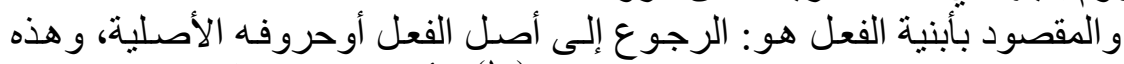

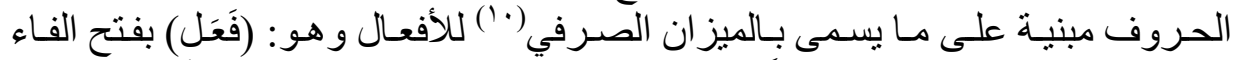

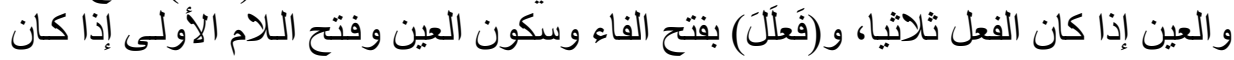

و أبنية الأفعال التي وردت في ديوان الثـافعي هي: (فعَل) بفتح العين، و(فعِل) رباعيا.

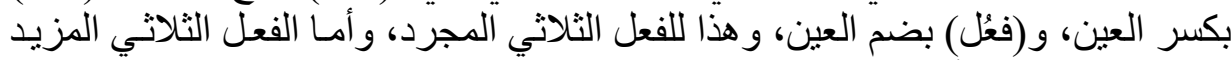

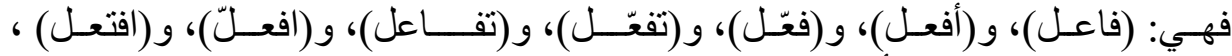

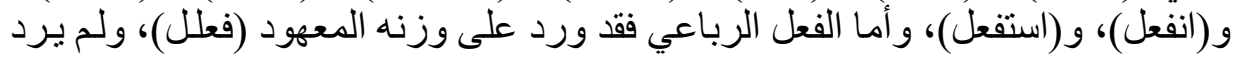
فيه الفعل الرباعي المزيد على والمي الإطلاق. و لأبنية الأفعال قيمة كبيرة في الإطناء الجئ الجملة، منها:

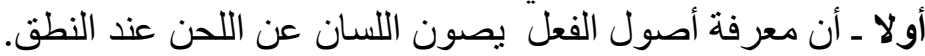

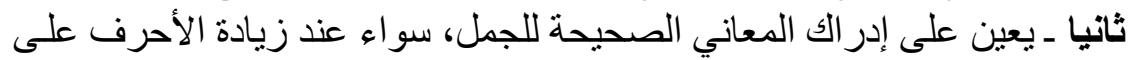
ألفاظ الفعل أو عند تجريدها عن الزئ الزو ائد.

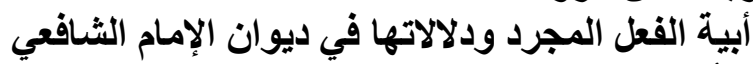

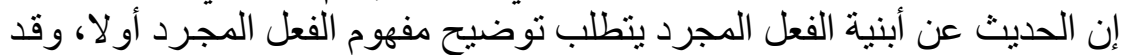

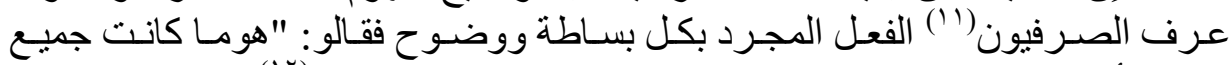

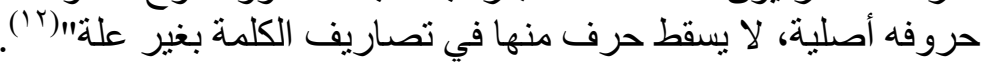

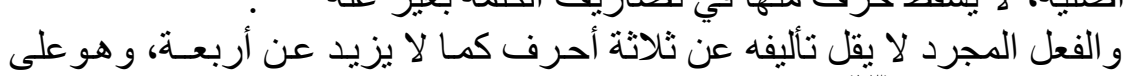

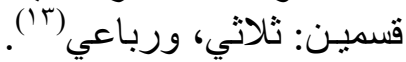

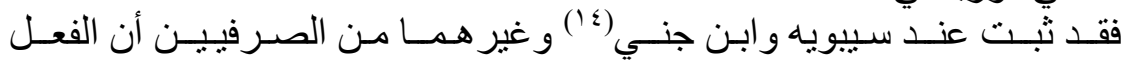

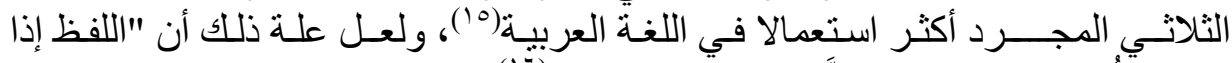

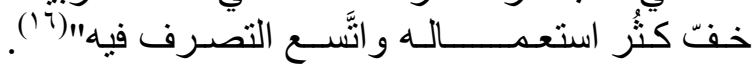

'. ـ هو معيار لفظي اصطلح الصرفييون على اتخاذه من أحرف "فعل" لوزن الكلمات العربية القابلة للتصريف.

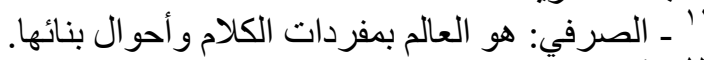

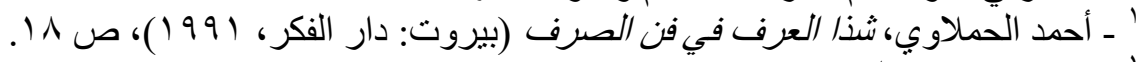

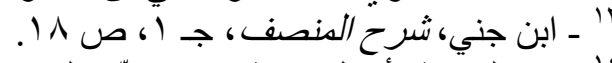

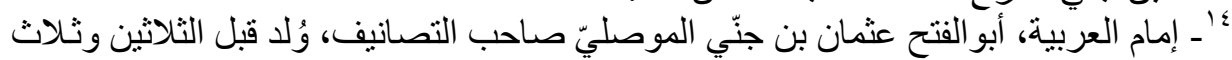

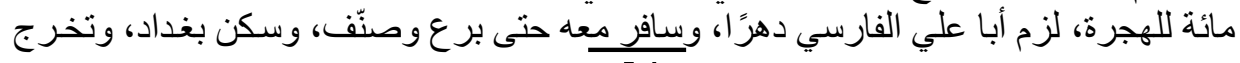




\section{ويأتي الثناثي المجرد على ثناثة أوزان هي:}

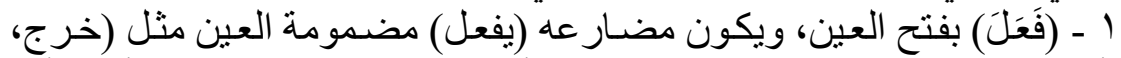

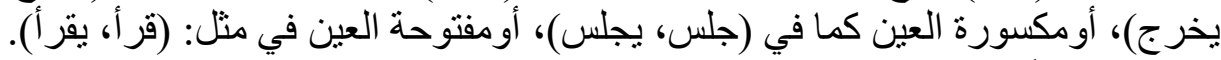

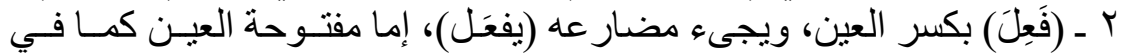

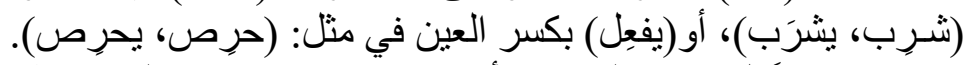

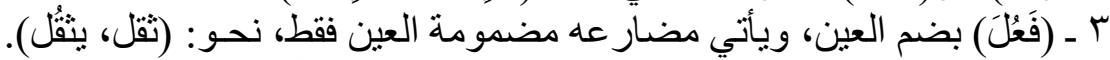

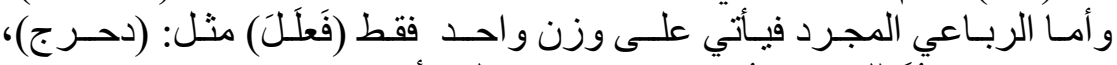

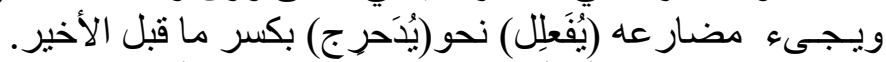

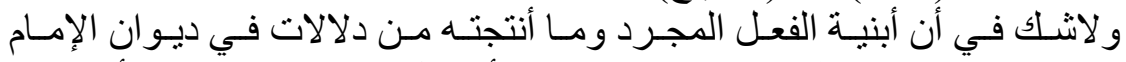

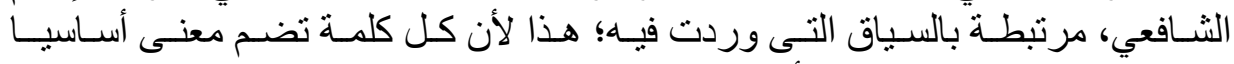

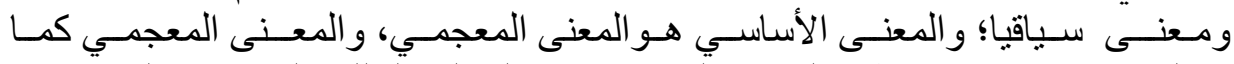

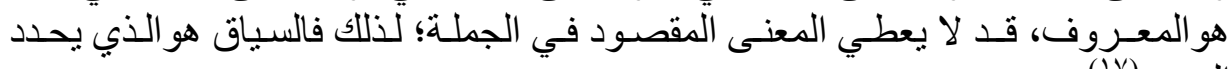
المعنى (iv) (1v) وقد وردت هذه الأبنية في ديوان الثافعي في سياقات مختلفة، وسوف يتم عرض في الإن

$$
\text { بعض من هذه الأبيات ودلالتها في الابية في ديوان السطور اللاحقية. }
$$

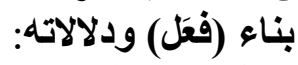

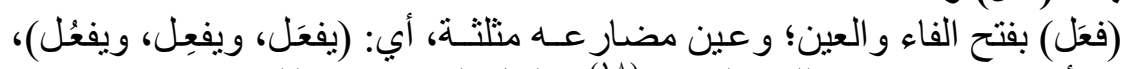

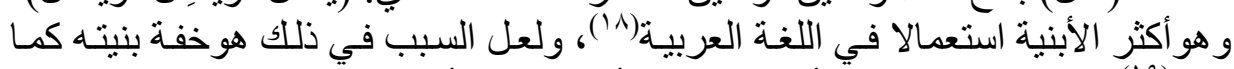

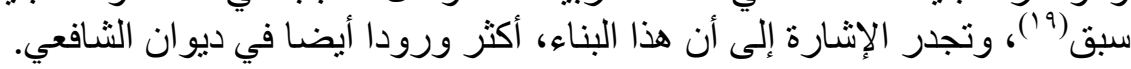

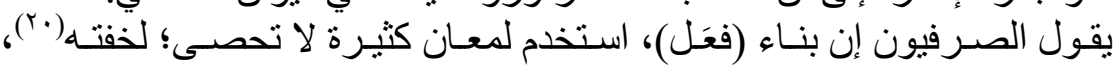

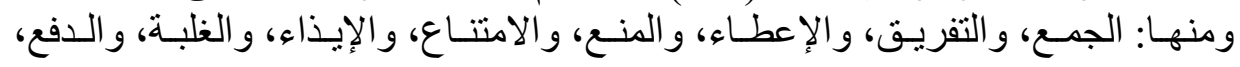

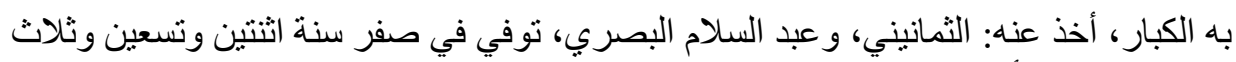

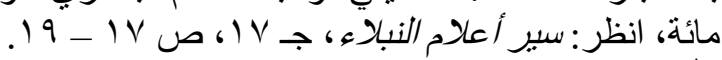

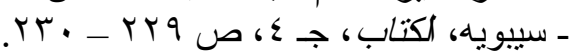

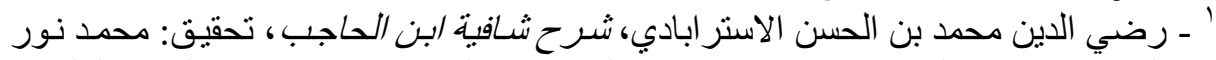

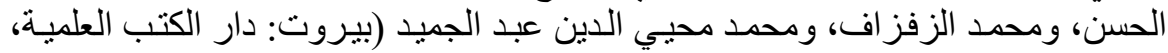

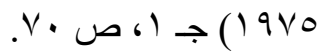
'ا' - بيير جيرو، علم الدلالة، نرجمة: الدكتور منذر عياشي (دمشق: دار طلاس، ب99 (1))، ص .07

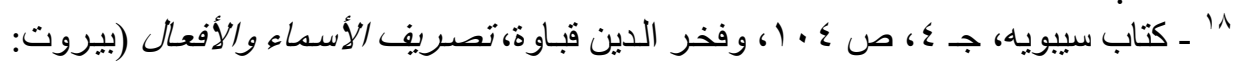

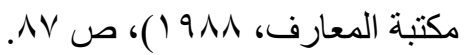
$9 r$ 


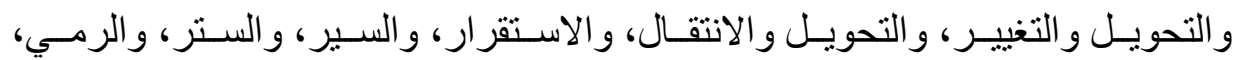

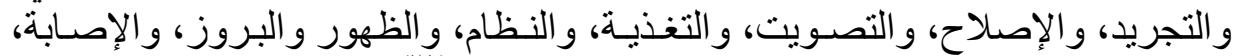

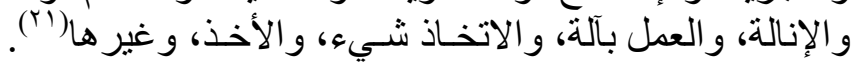

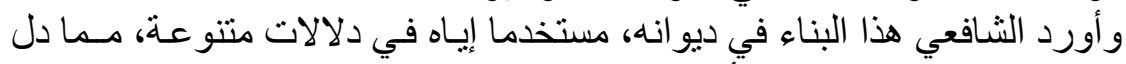

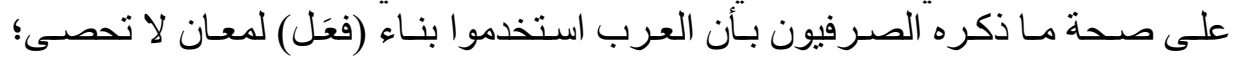
لخفته على اللسان، ومن هذه الدلالات و المعاني التي وردت العرب في ديو انه:

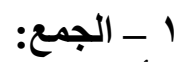

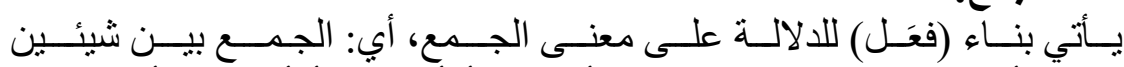

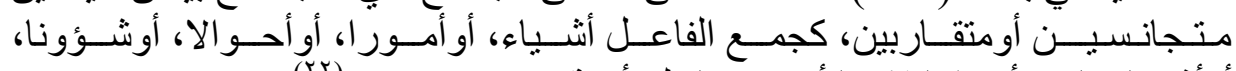

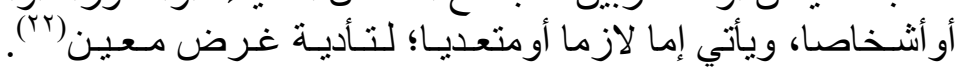

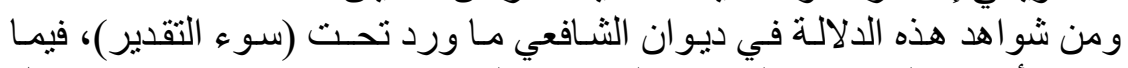

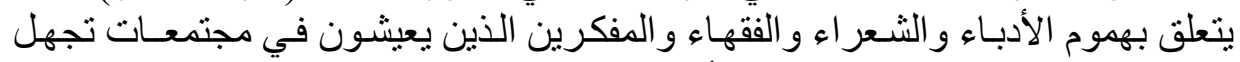

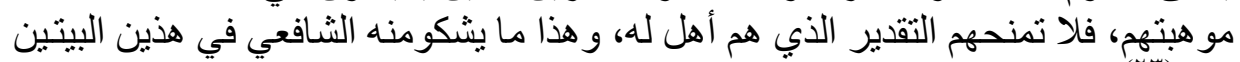

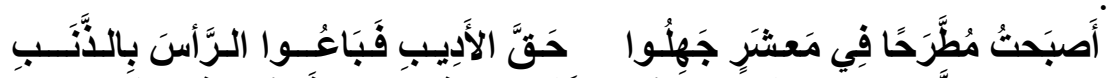

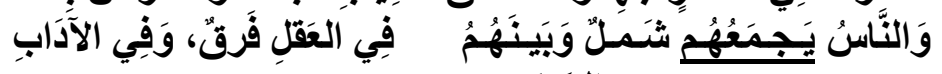

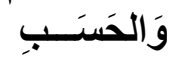

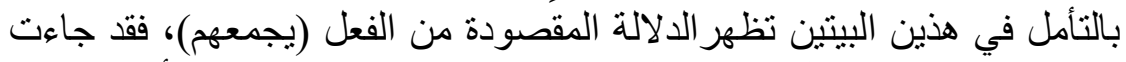

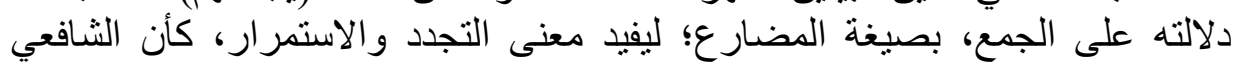

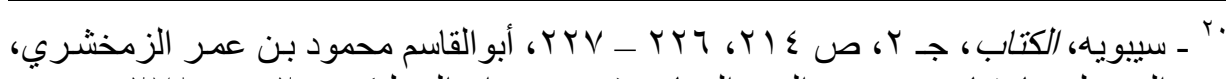

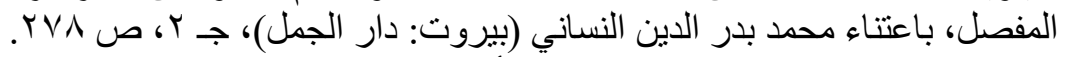

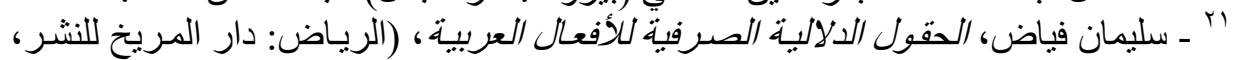

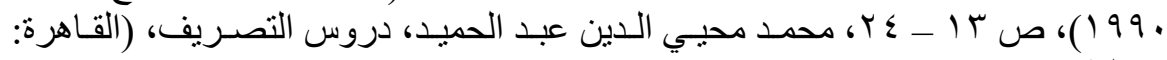

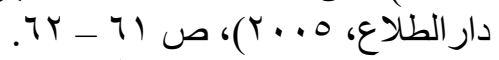

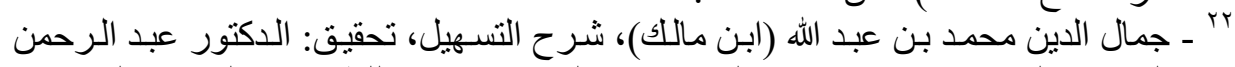

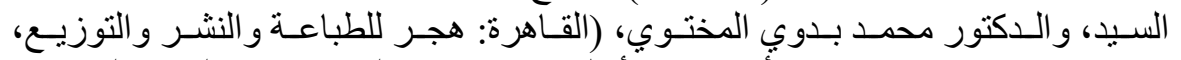

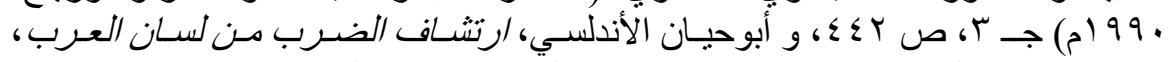

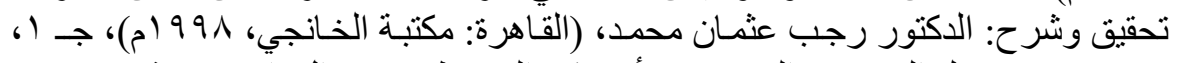

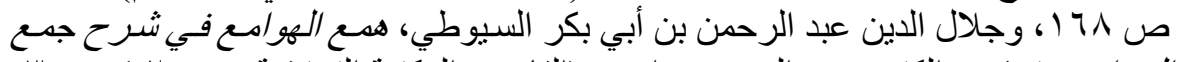

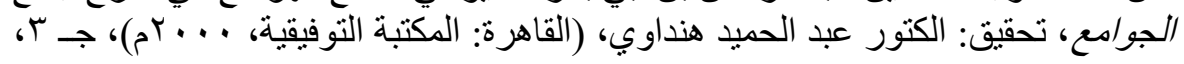

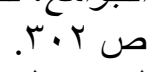

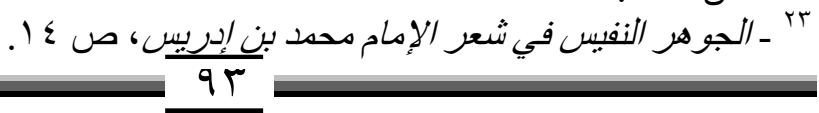




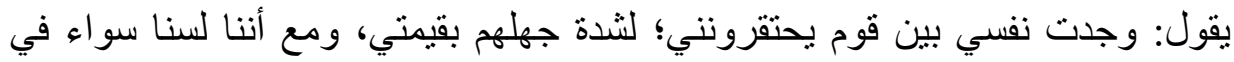

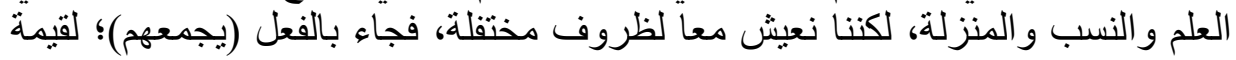

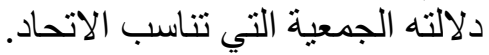

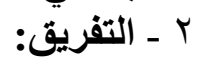

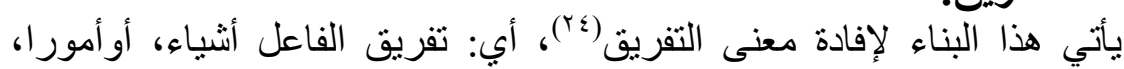

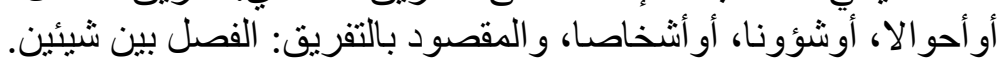

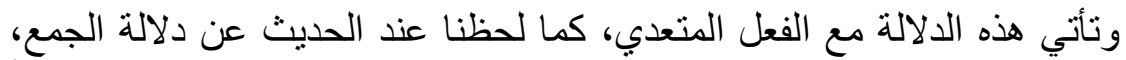
في قصيدة (سوء التقدير)، وقد جاء في القصيدة ذاتها ما يشير إلى دلالة التفريق، إذ بدأ

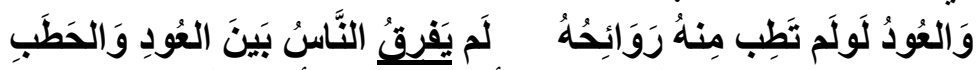

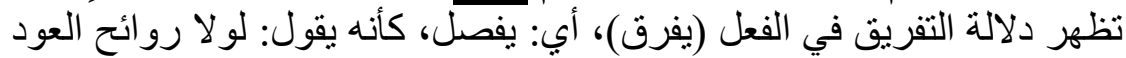

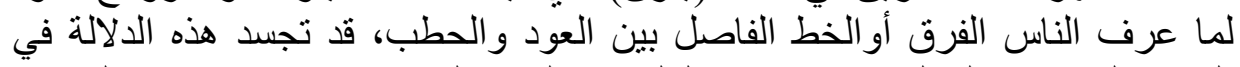

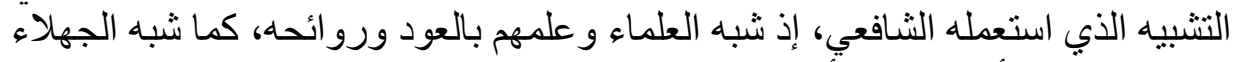
بالحطب، مبينا بأن العلم، هو أساس التمبيه التيز بين العالم وغيره من الناس. بناء (فِعل) ودلالاته:

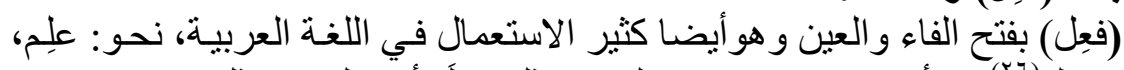

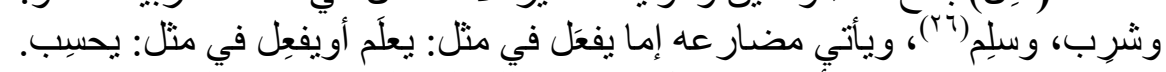

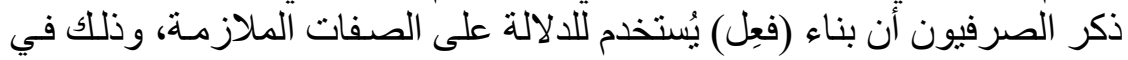

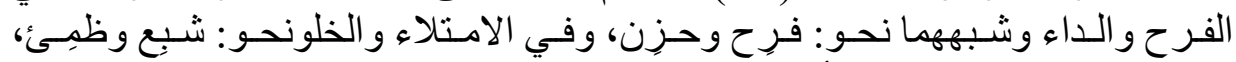

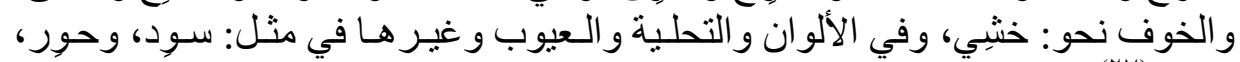
وشتنر (rv)

وقد استخدم الإمام الثـافعي هذا للالالة على الفر ح و الداء، و العيب، والامتلاء

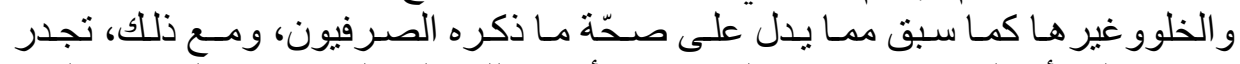

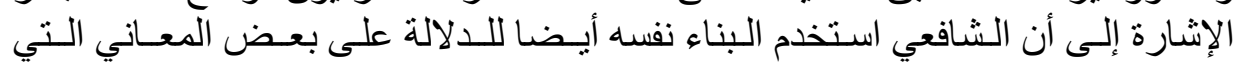

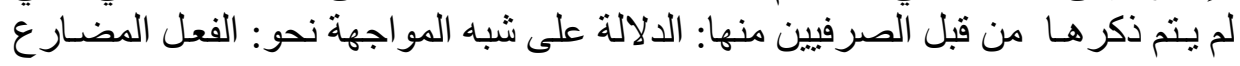

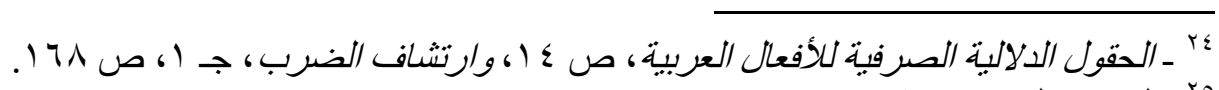

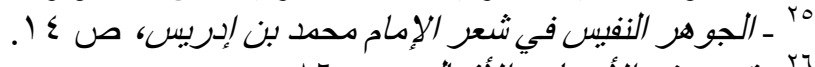
rir

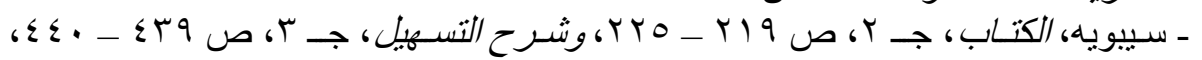

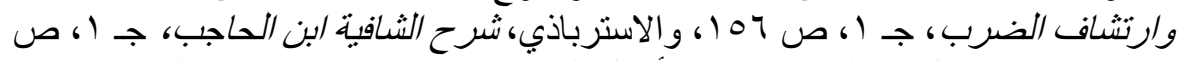

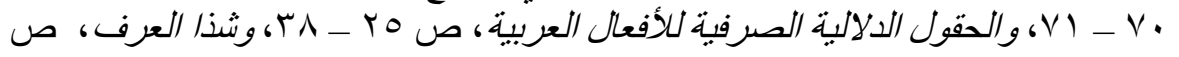




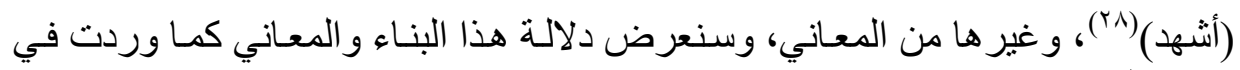
ديوان الثنافعي: 1 ـ العلل:

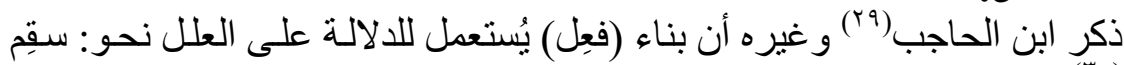

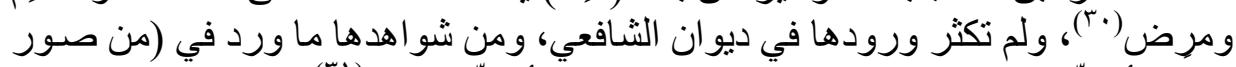

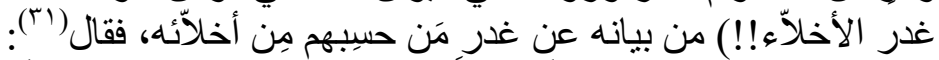

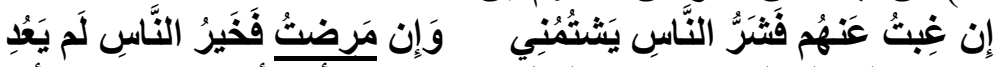

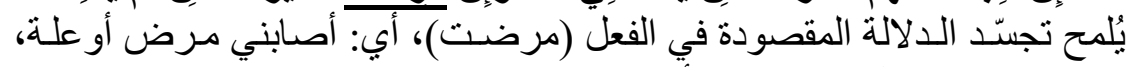

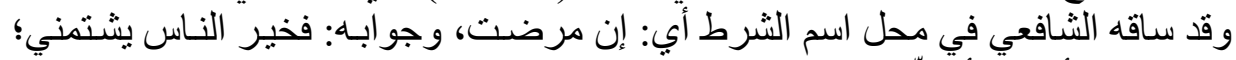

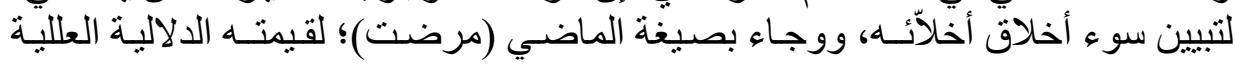

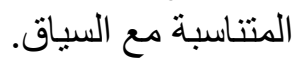

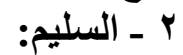

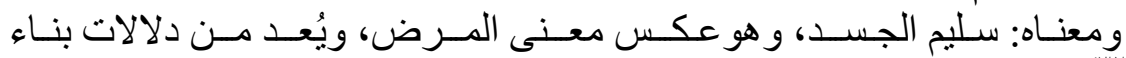

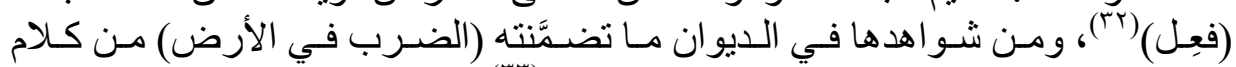

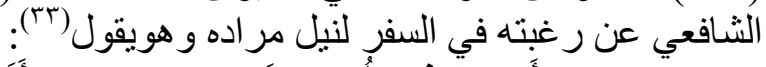

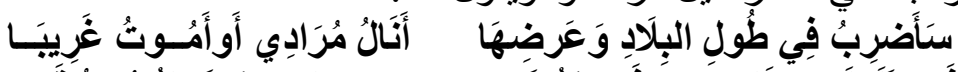

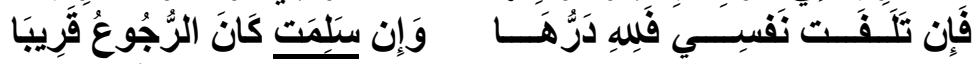

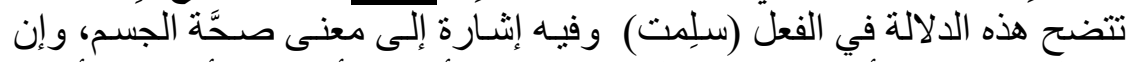

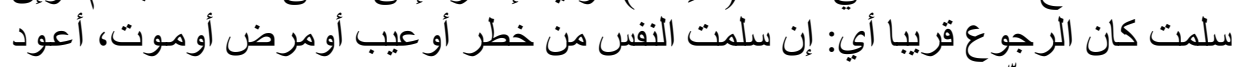
إلى بلدي وقد حقّت آمالي.

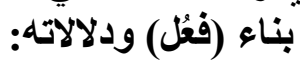

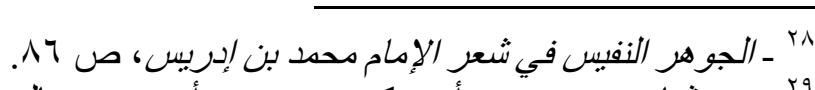

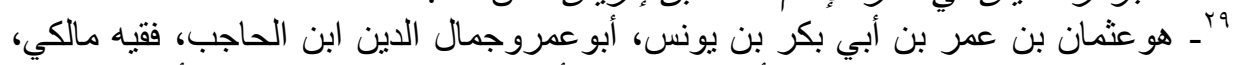

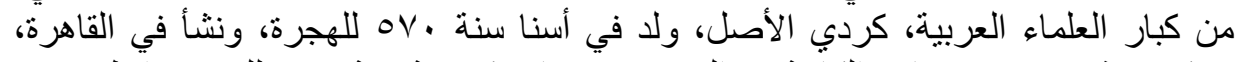

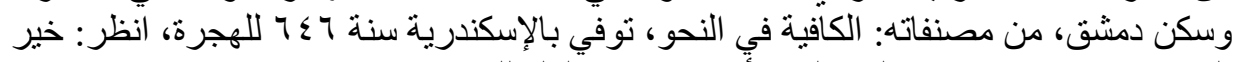

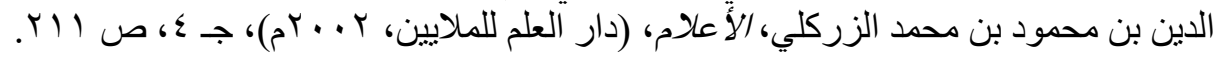

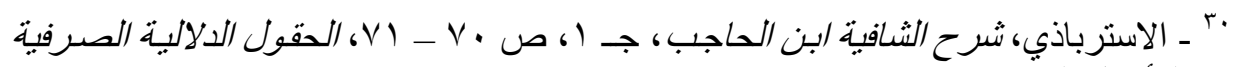

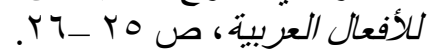

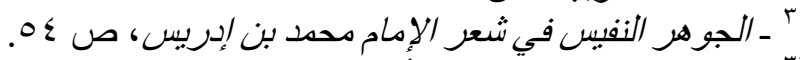

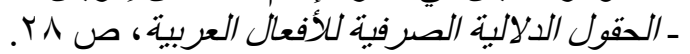

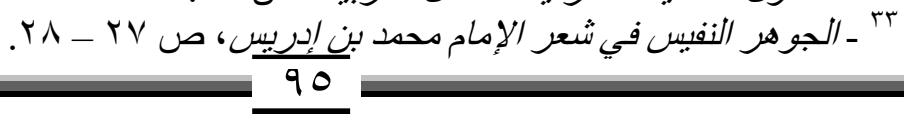




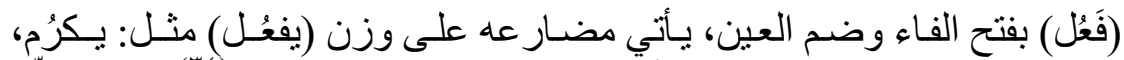

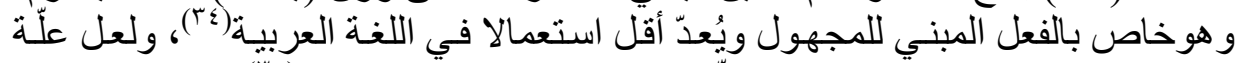

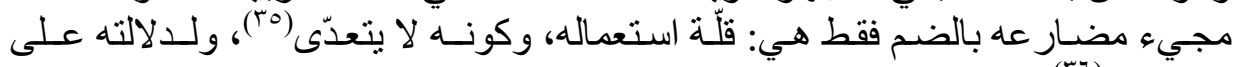
الاتصناف(؟T)

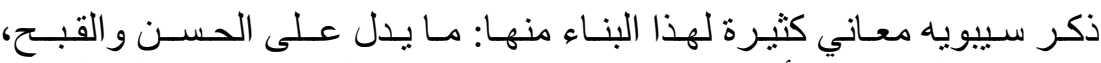

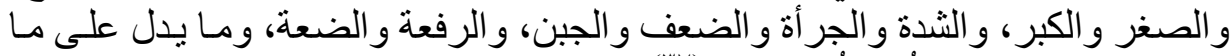

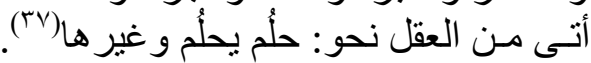

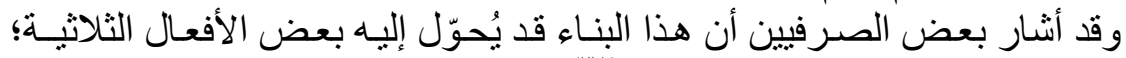

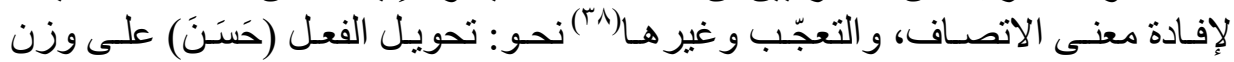

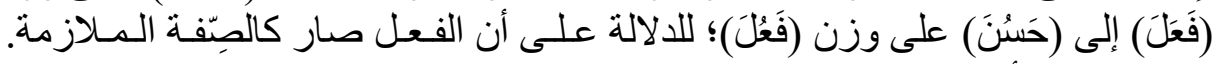

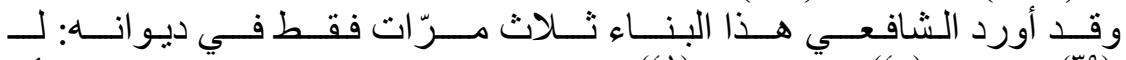

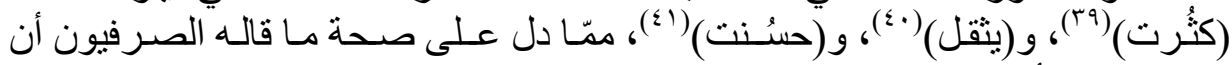
هذا البناء هو أقل استعمالا في اللغة العربية.

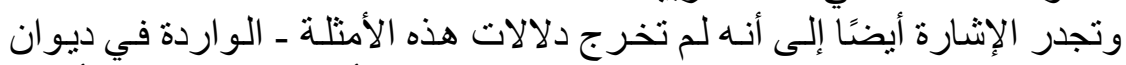

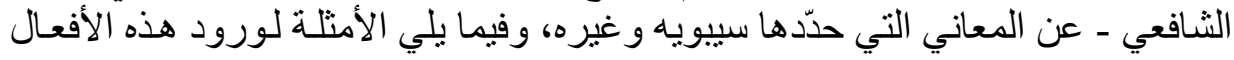
في الديوان: - الدير:

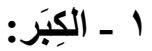

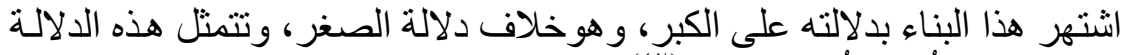

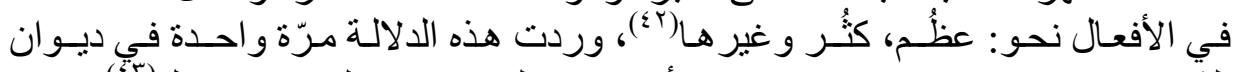

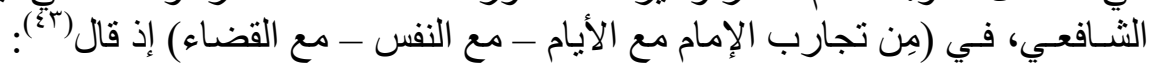

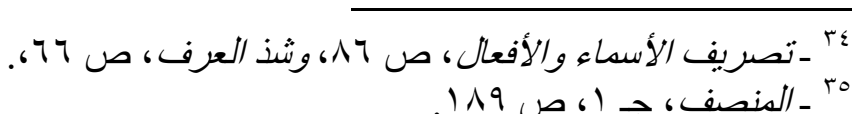

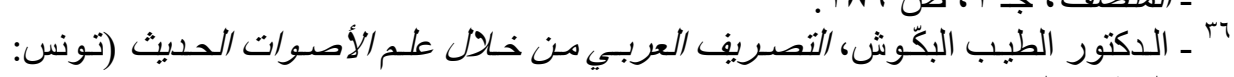

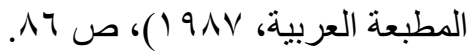

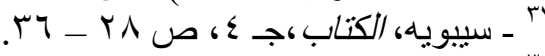

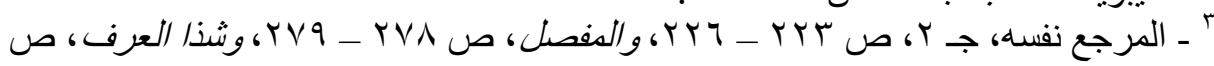

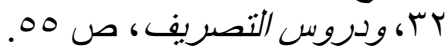

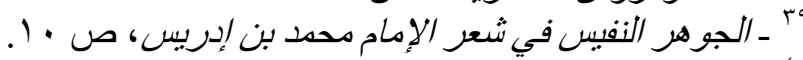

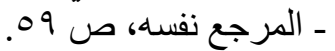

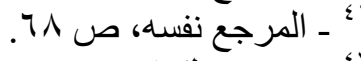

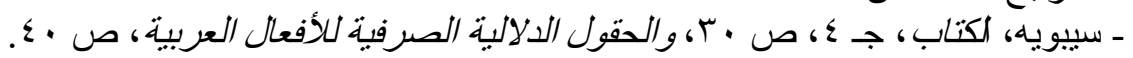

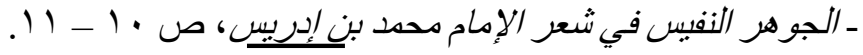




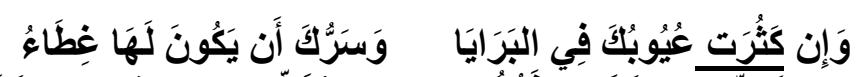

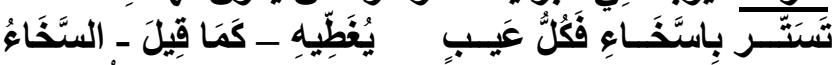

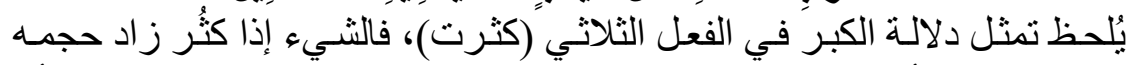

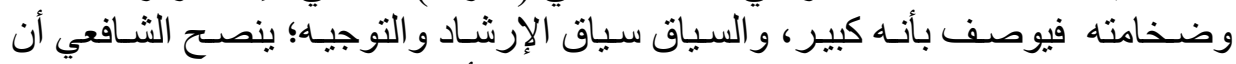

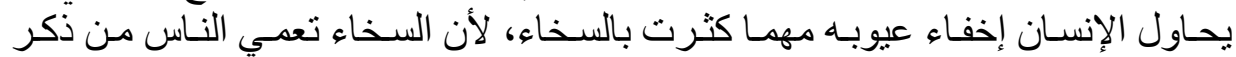
عيوبه الكثيرة. r ـ الحُسن:

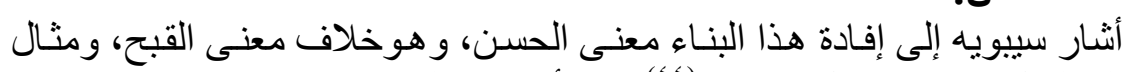

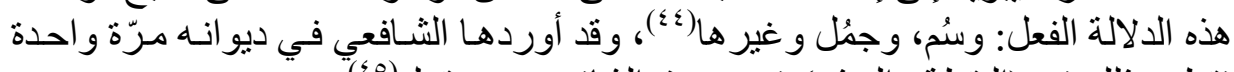

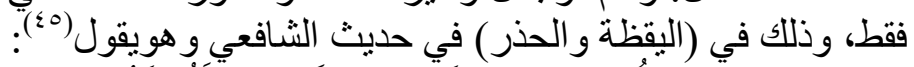

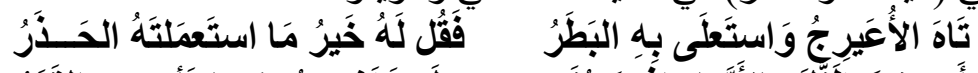

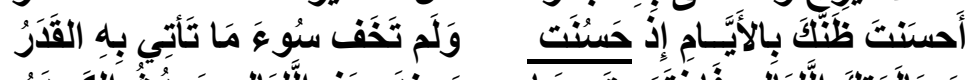

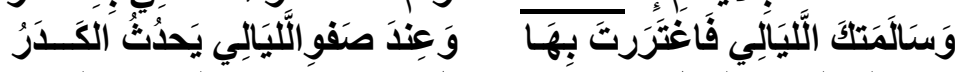

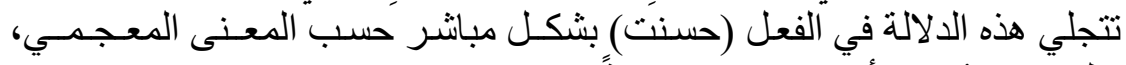

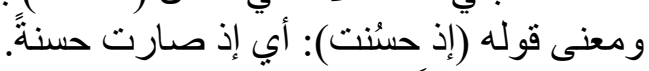

$$
\begin{aligned}
& \text { بناء (فعلَل) ودلالاته }
\end{aligned}
$$

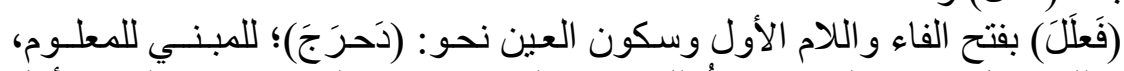

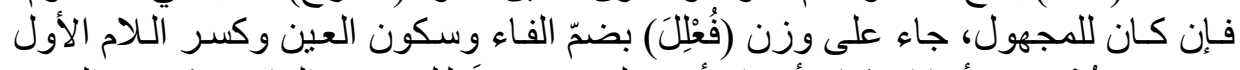

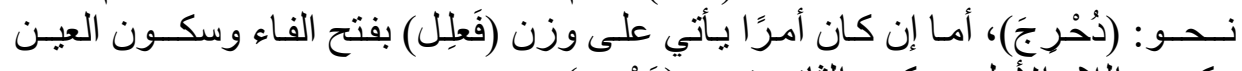

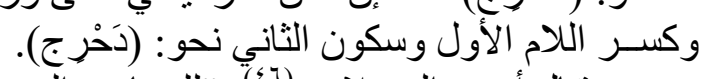

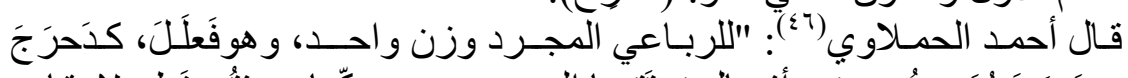

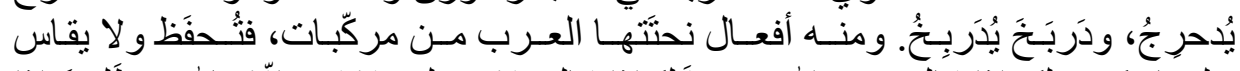

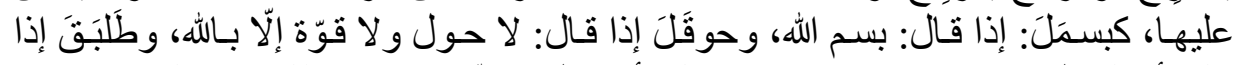

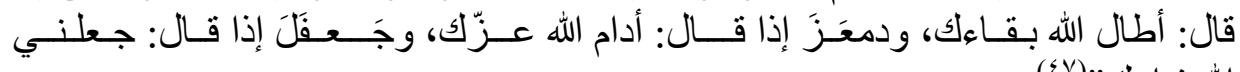

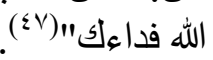

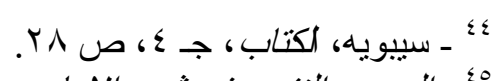

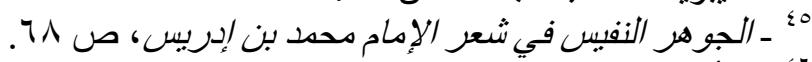

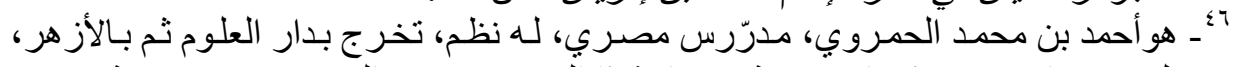

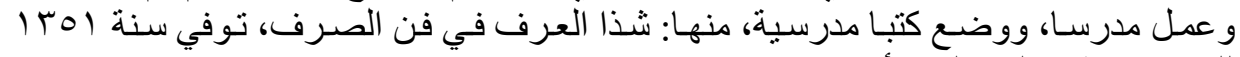

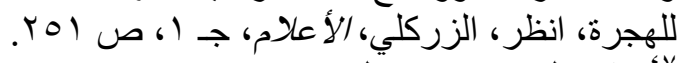
$9 V$

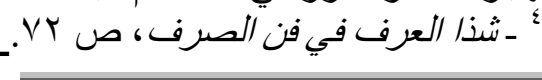




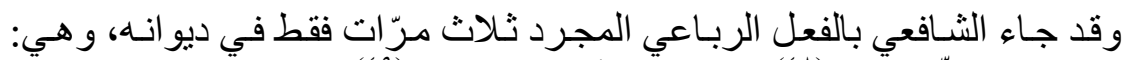

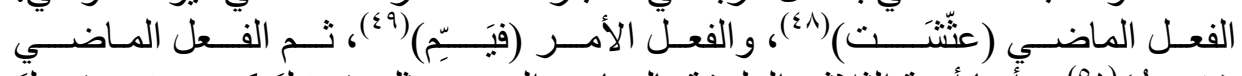

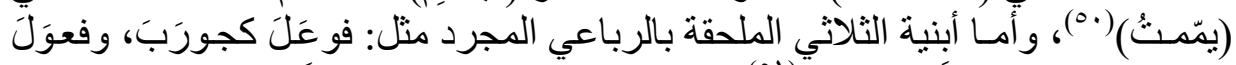

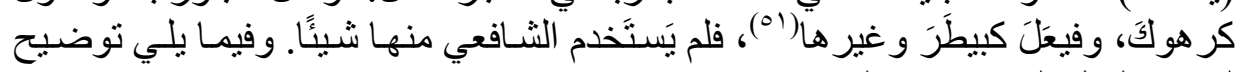

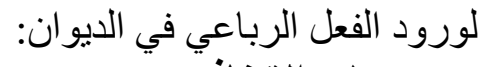
1 ـ الاتخاذ:

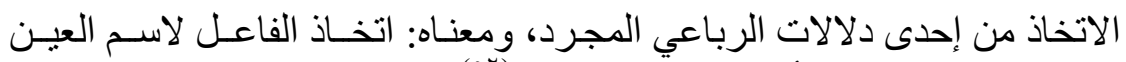

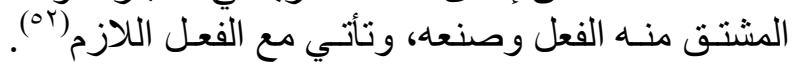

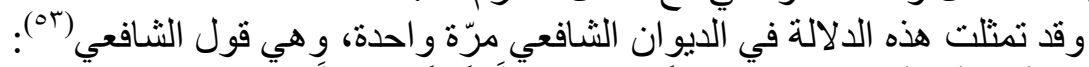

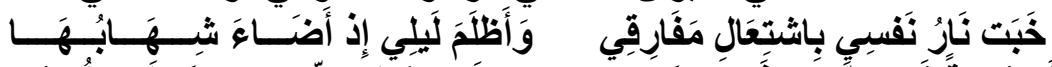

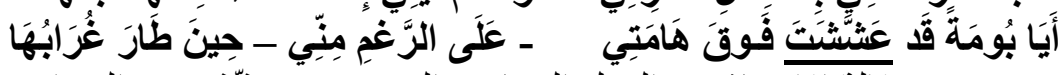

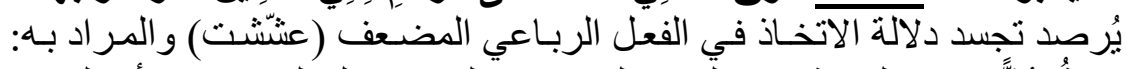

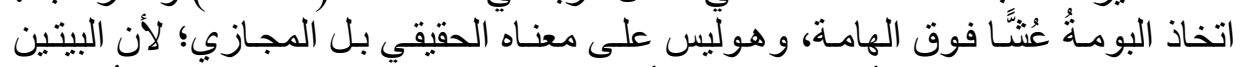

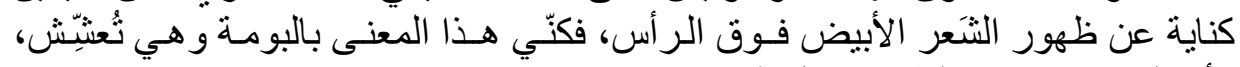

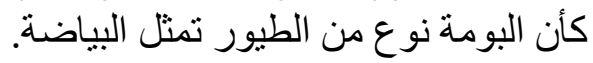

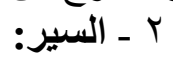

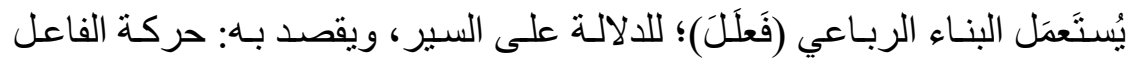

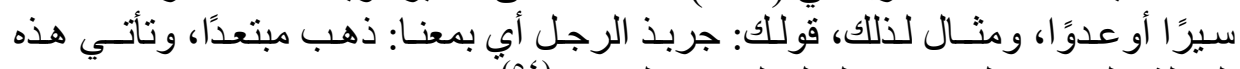

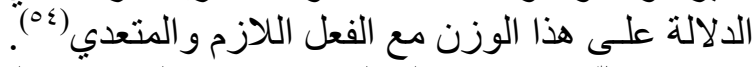

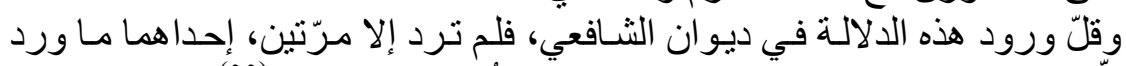

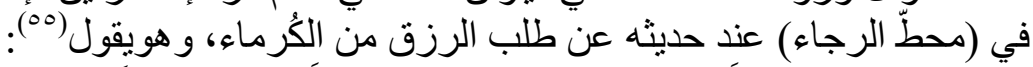

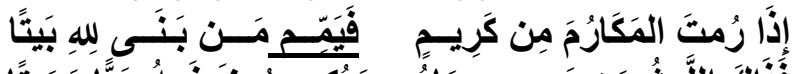

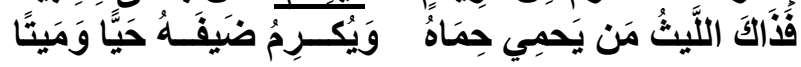

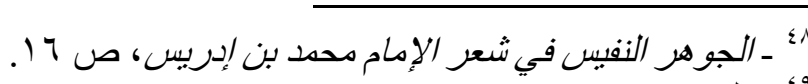

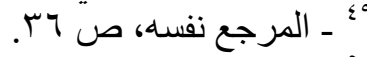

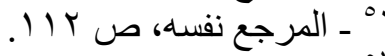

$$
\begin{aligned}
& \text { Pr }
\end{aligned}
$$

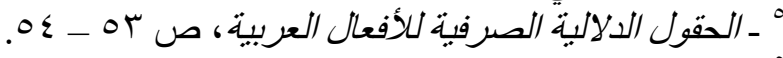

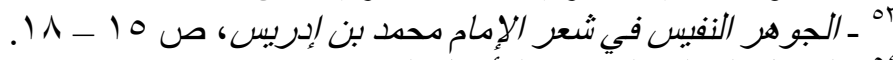

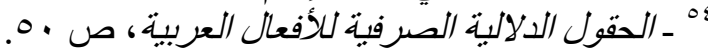

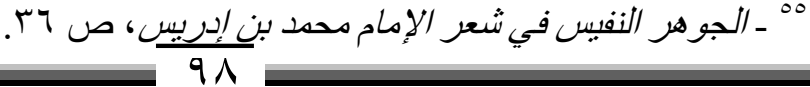




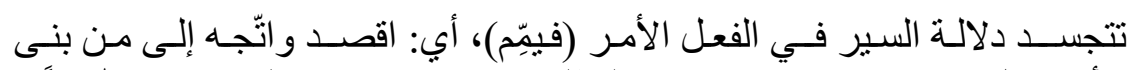

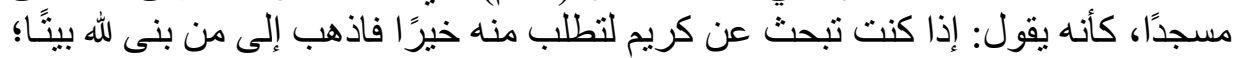

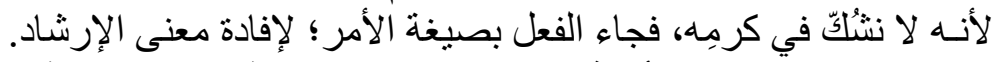

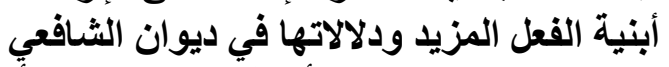

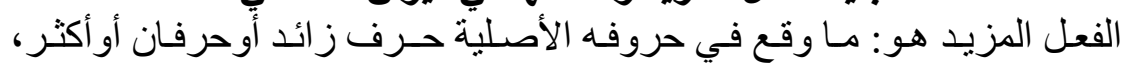

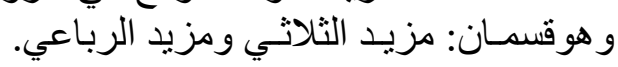
1

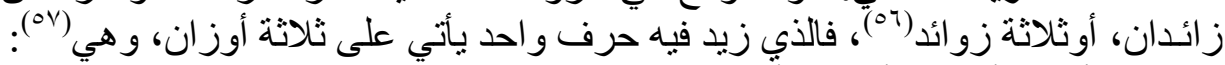

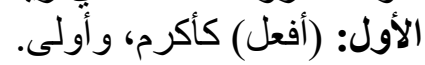

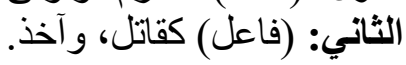

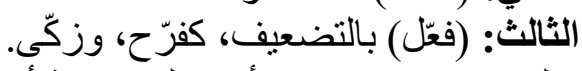

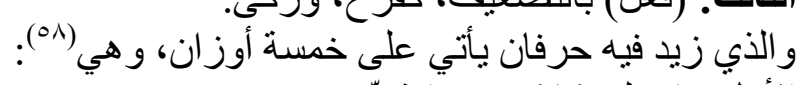
الأول: (انفعل) كانكسر ، وانشقيّ.

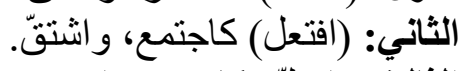

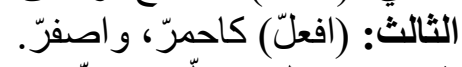

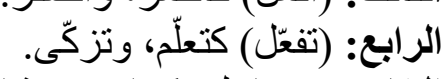

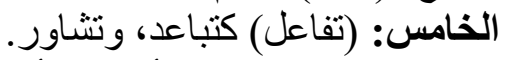

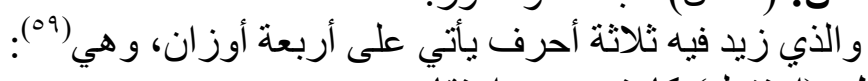

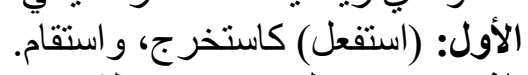

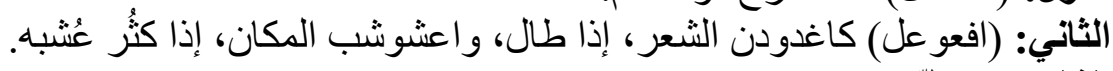

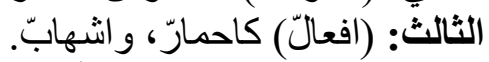

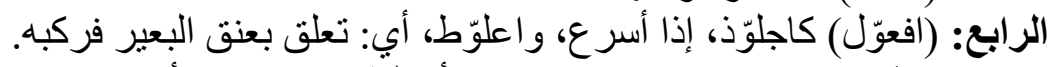

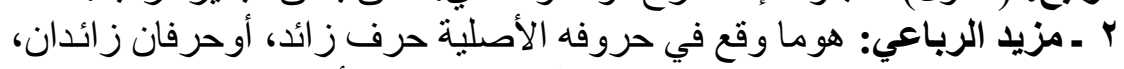

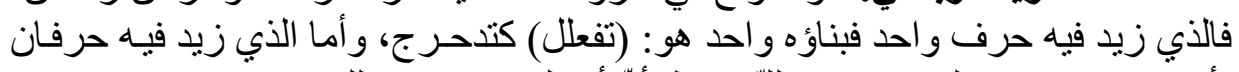

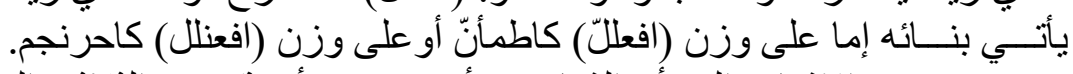

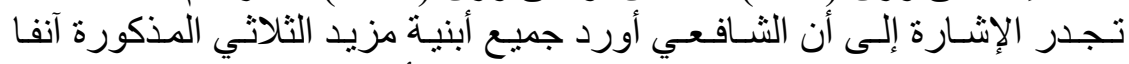

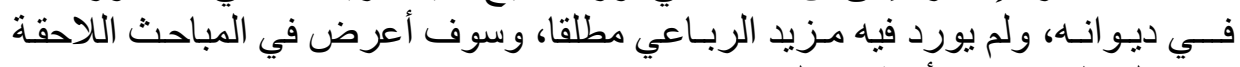
نماذج لتوظيف هذه الأبنية في الديوان.

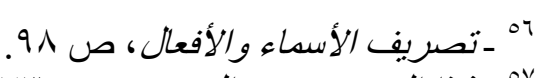

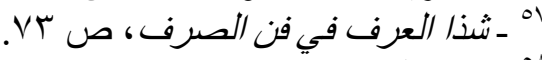
V

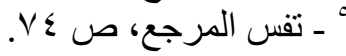




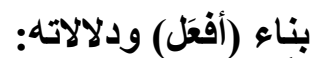

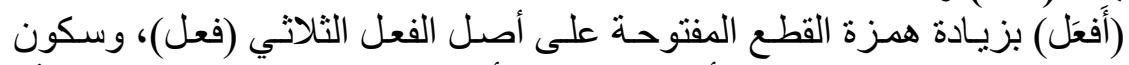

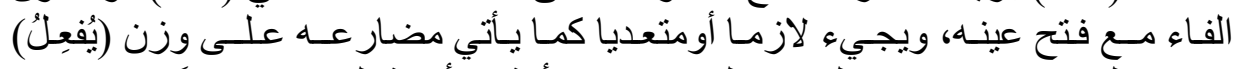

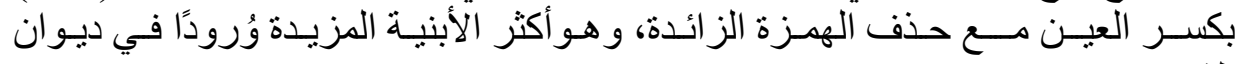

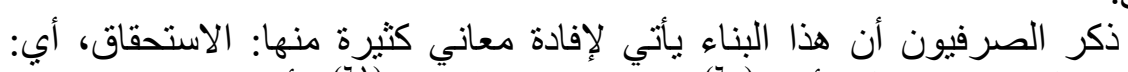

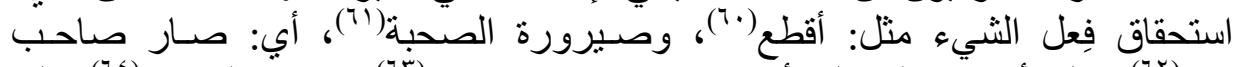

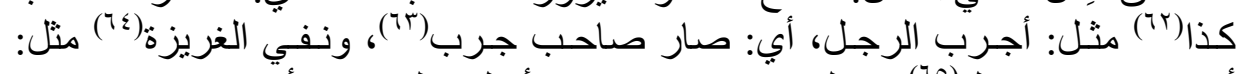

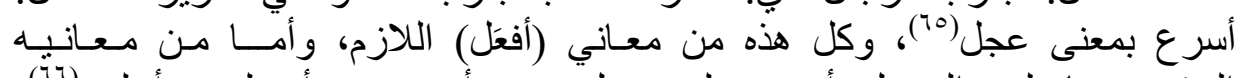

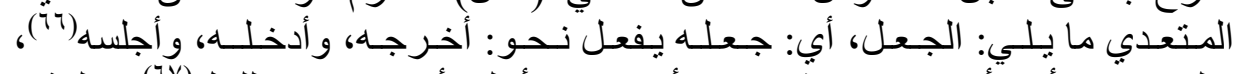

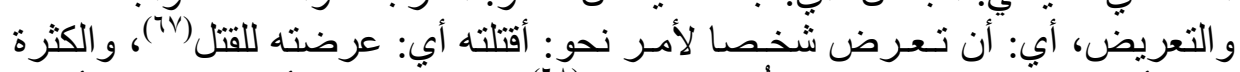

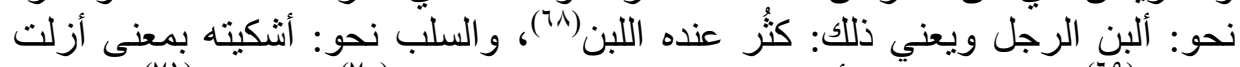

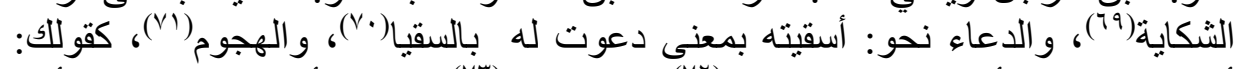

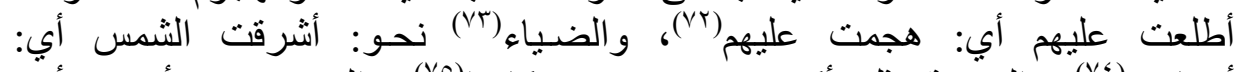

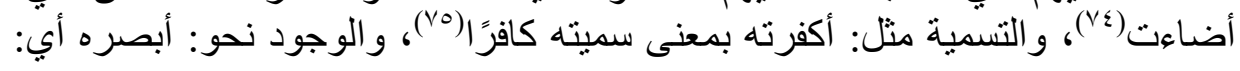

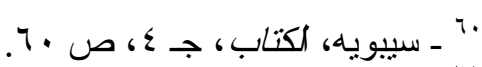
"" ـ أبوحيان الأندلسي، الدبدع في التصريف ، تحقيق وشر ح وتعليق: الكتور عبد الحميد السيد

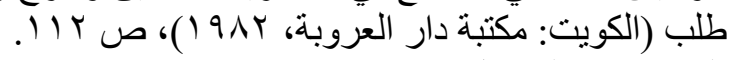

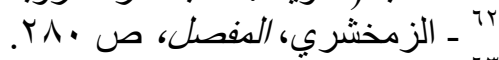

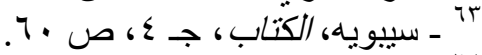

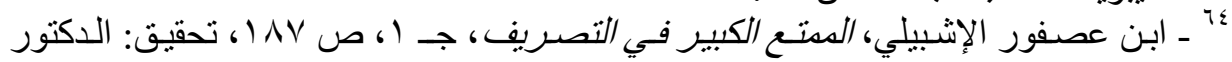

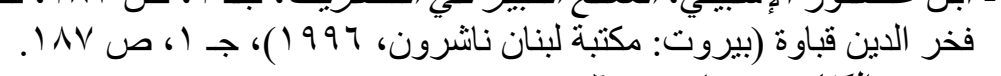

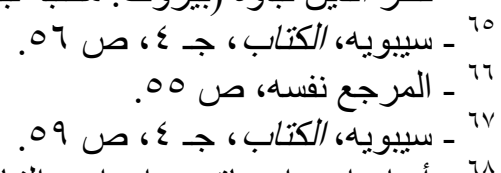

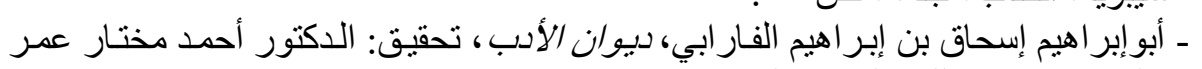

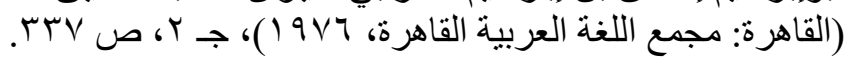

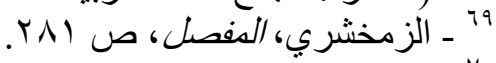

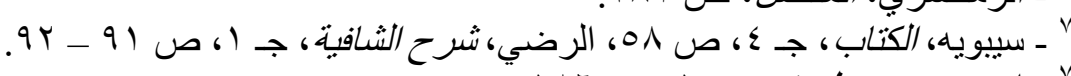

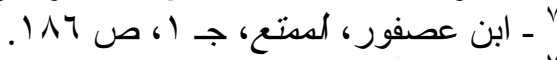
ال

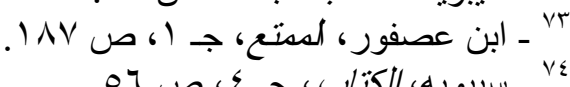




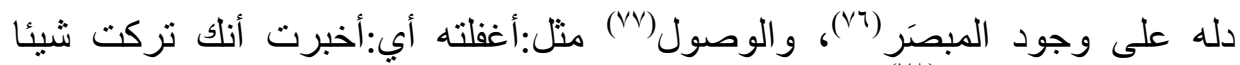

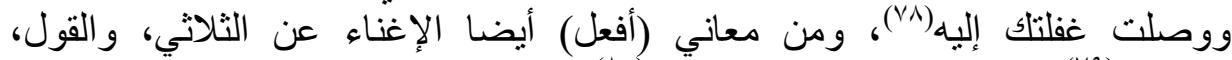

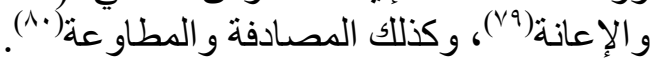
ومن دلالات (أفعل) التي تم استعمالها في ديو ان الثنافعي ما يلي:

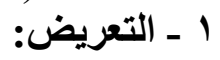

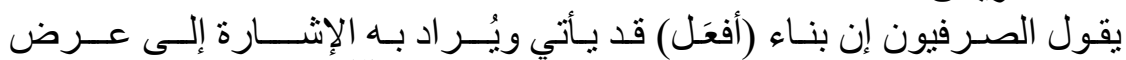

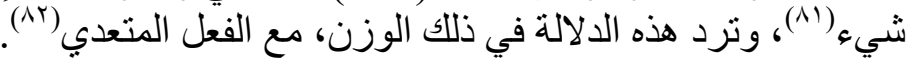

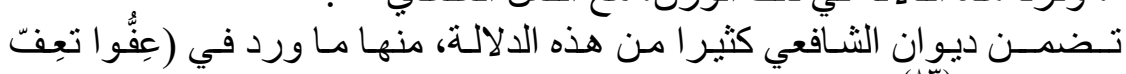

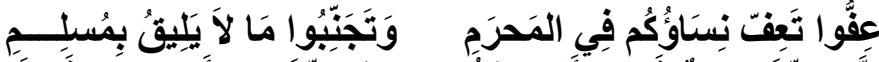
نساؤك!!!) حيث قالِ (Ar)

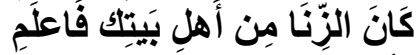

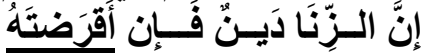

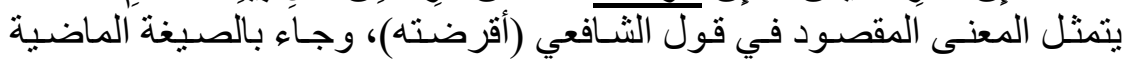

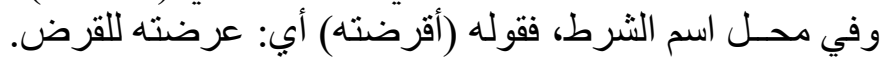

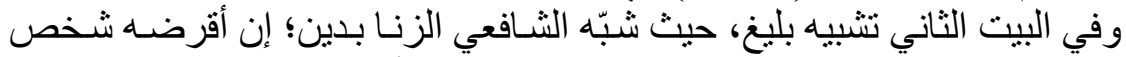

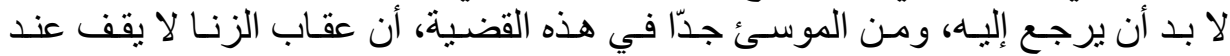
صاحبه فق طـ أي: الذي فعله، بل قد يمتد إلى أهل بيته كذللك.

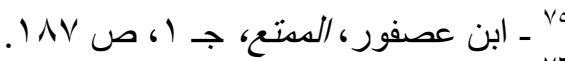

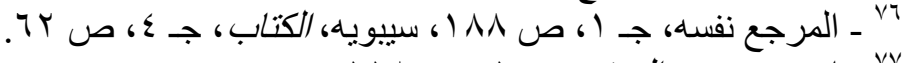

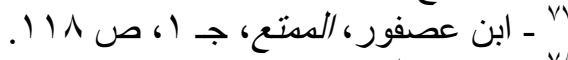

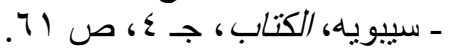

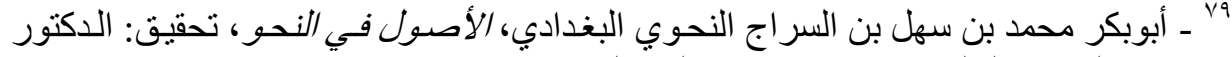

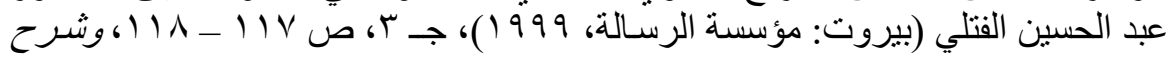

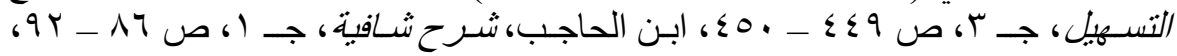

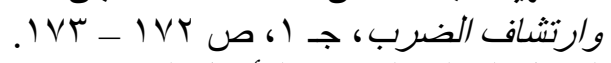

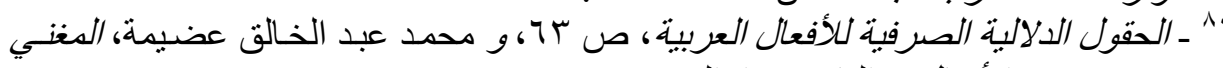

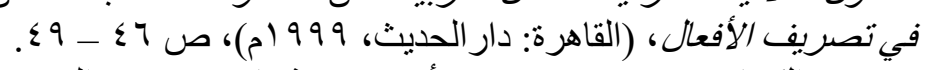

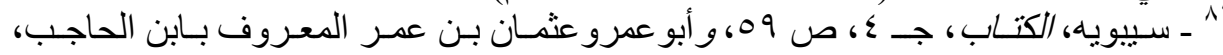

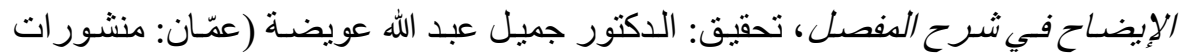

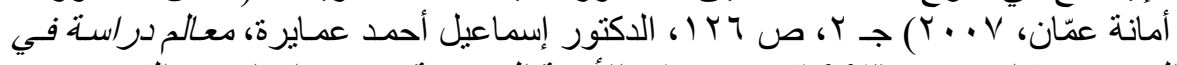

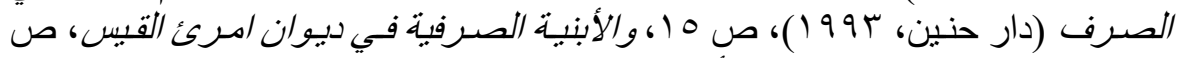

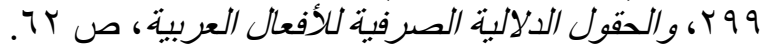

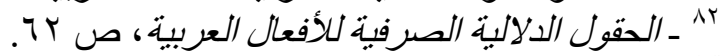

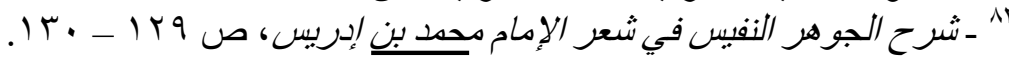




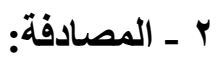

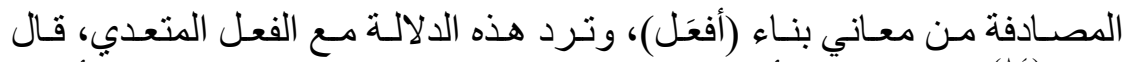

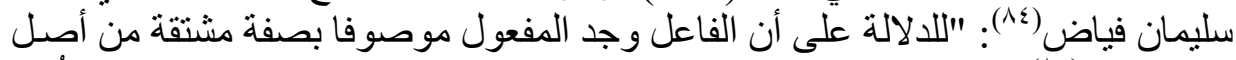

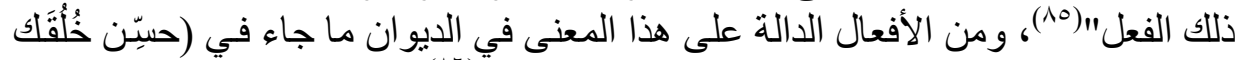

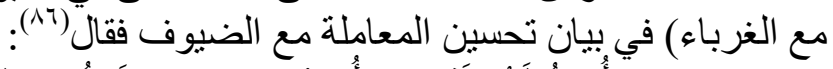

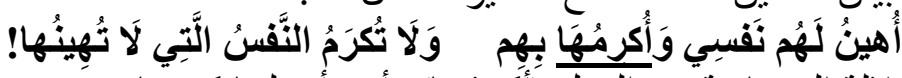

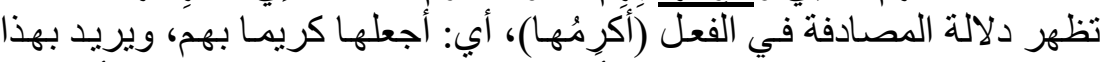

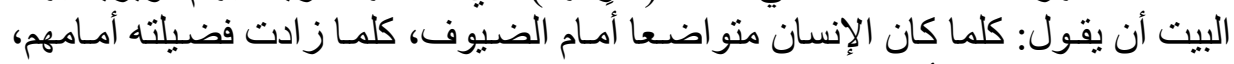

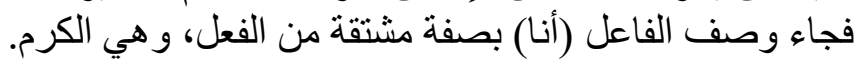

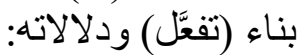

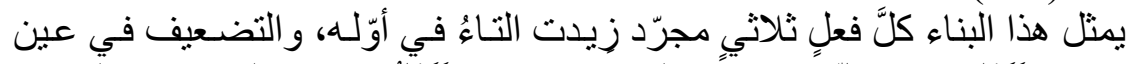

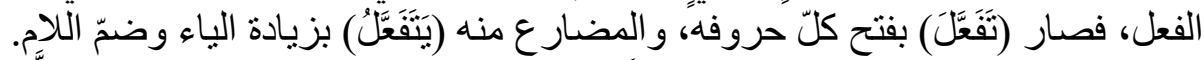

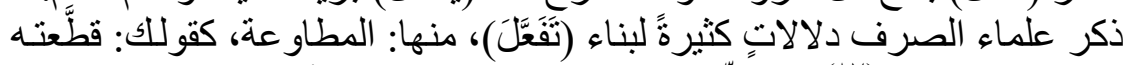

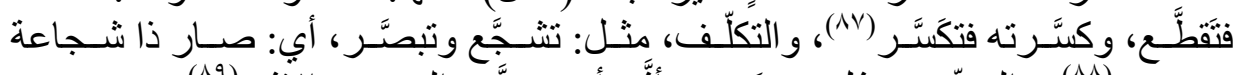

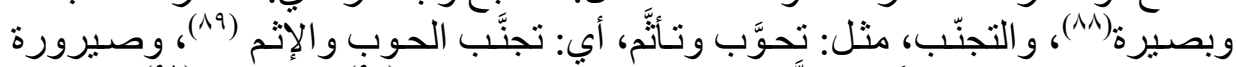

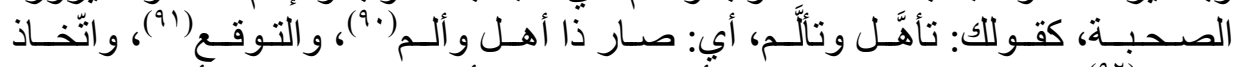

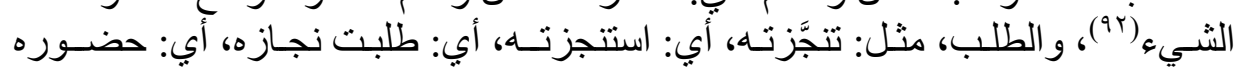

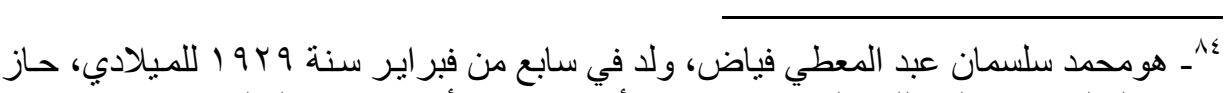

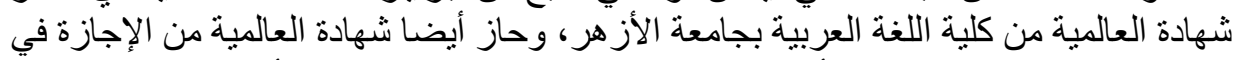

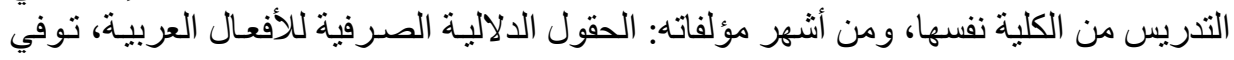

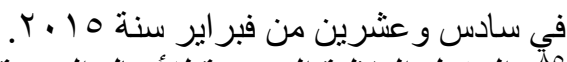

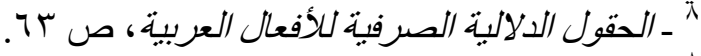

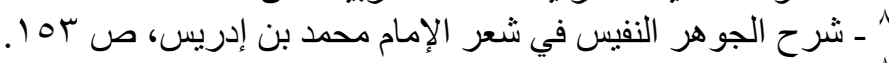

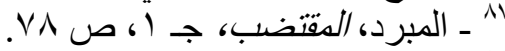

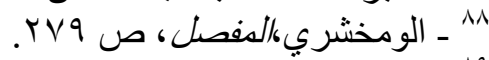

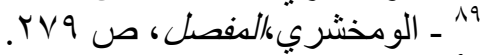

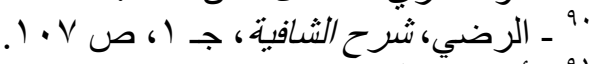

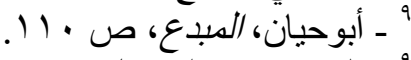

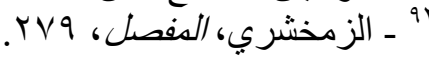




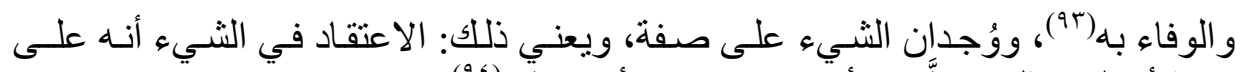

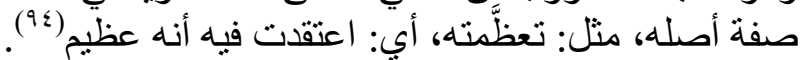

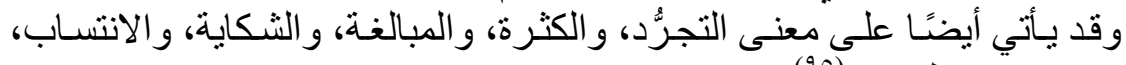

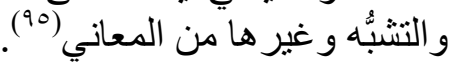
ومما ورد من هذا البناء بما يلي: البعان:

$$
\text { ـ التكلف: }
$$

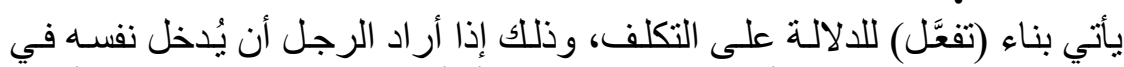

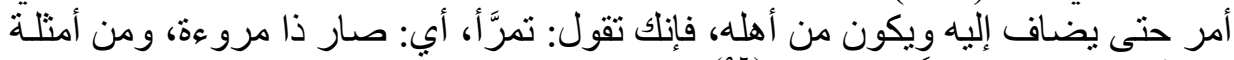

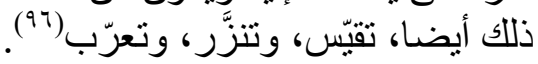

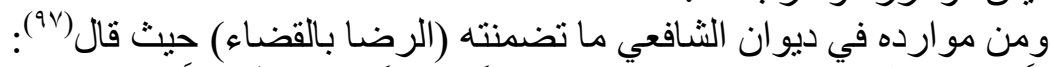

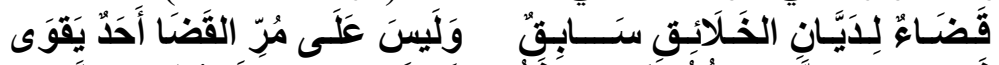

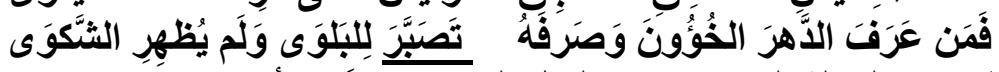

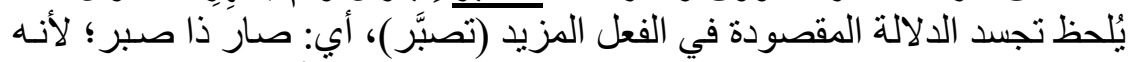

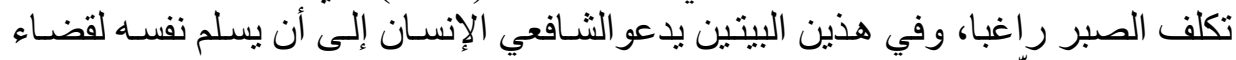

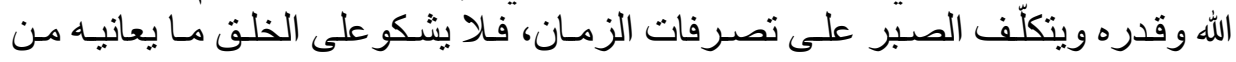
الصعوبات في.

\section{צ ـ التجنب:}

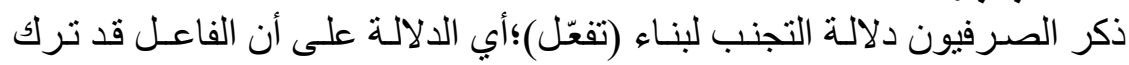

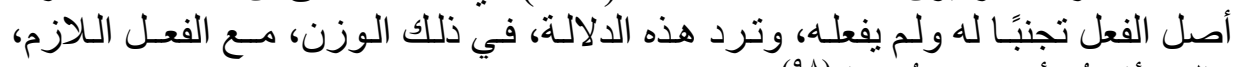

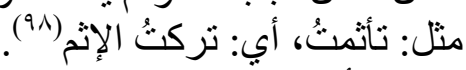

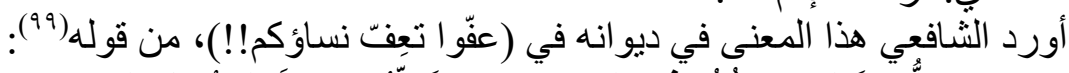

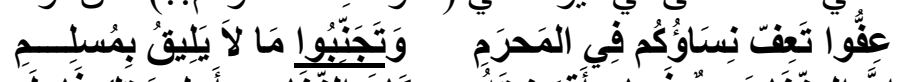

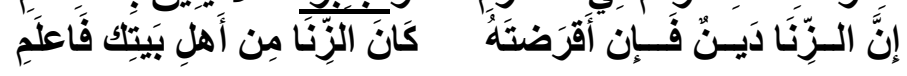

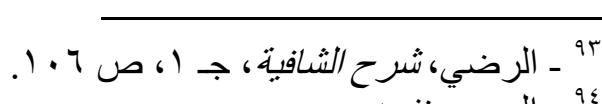

$$
\begin{aligned}
& \text { هو }
\end{aligned}
$$

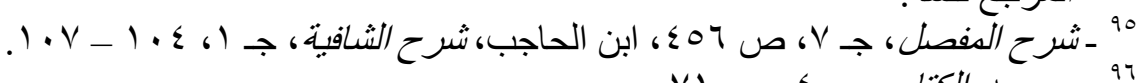

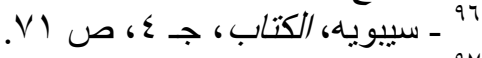

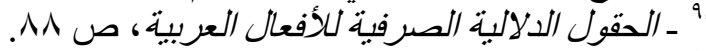

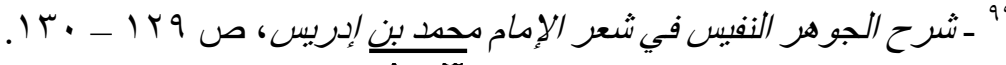




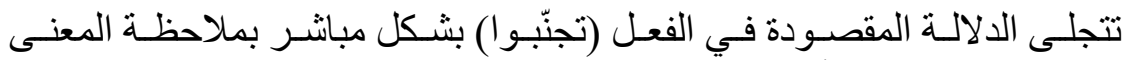

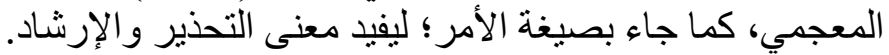
بناء (استقعل) ودلالاته:

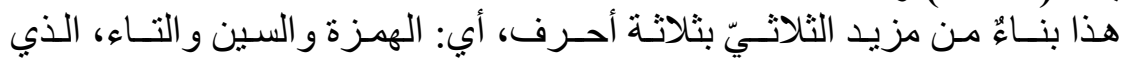

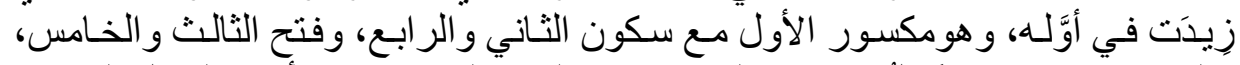

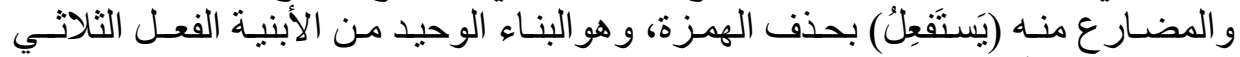

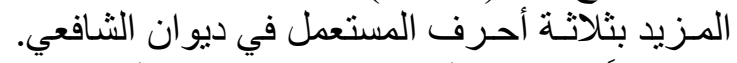

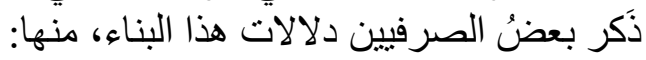

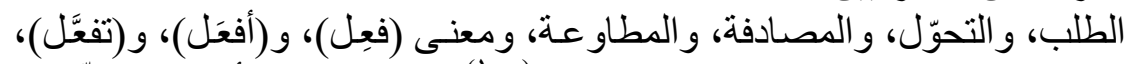

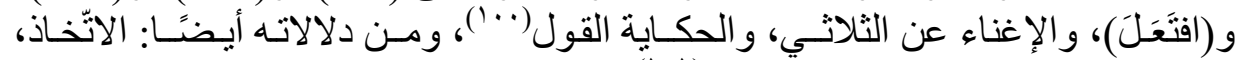

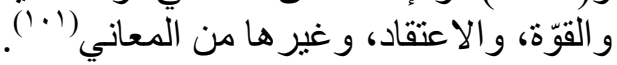

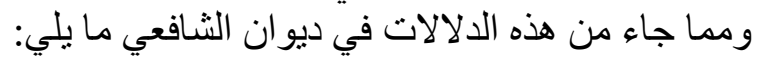
أبلب:

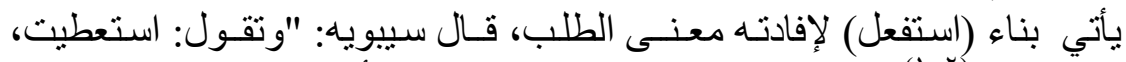

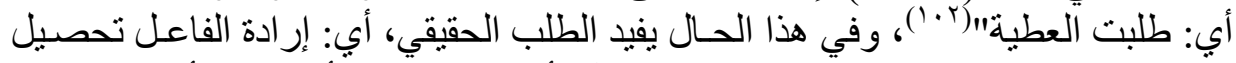

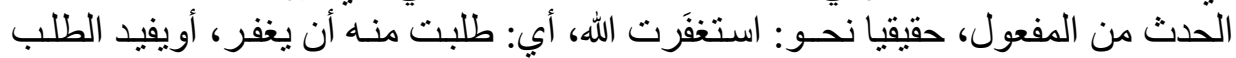

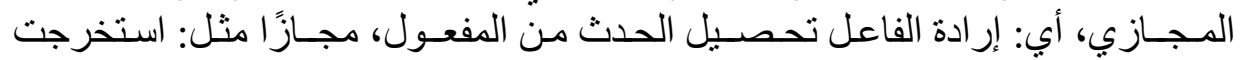

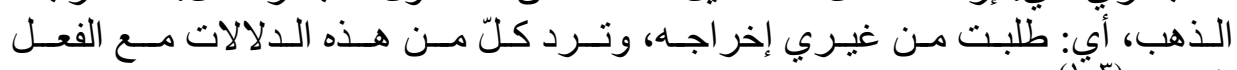

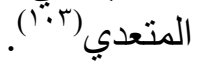
ومن شو اهد هذه الدلالة في الديوان الثـافعي مـا جاء في (مناجاة !!) حيث قال(

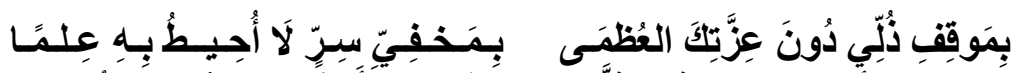

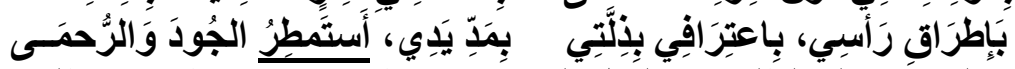

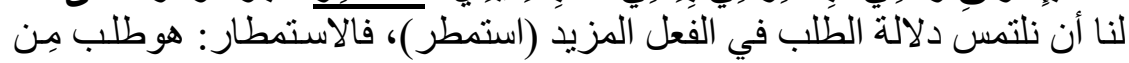

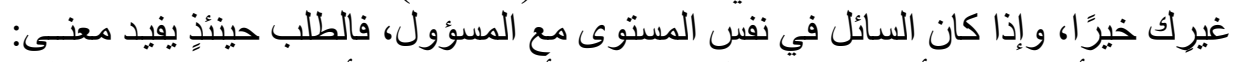
الالتماس، أمّا إذا كان أعلى من الَّائل، يكون قد أفـاد معنى: الأمر، لكن إن كان الطلب

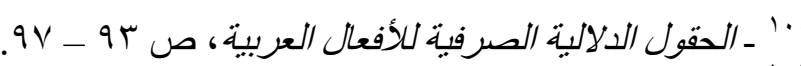

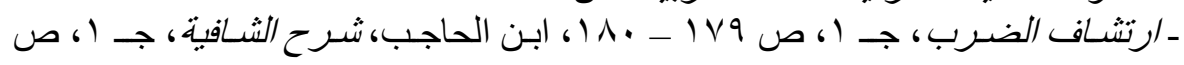
.111-11.

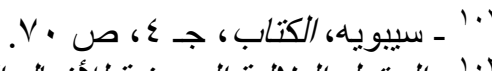

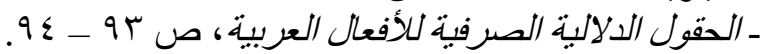

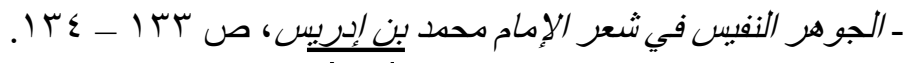




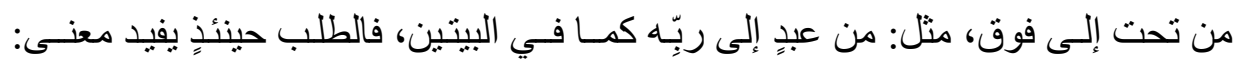

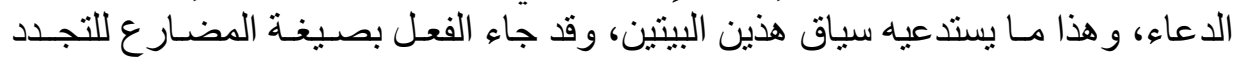
و الاستـــرار في طلب الثنافعي الجود و الرحمة من ربّهـ.

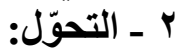

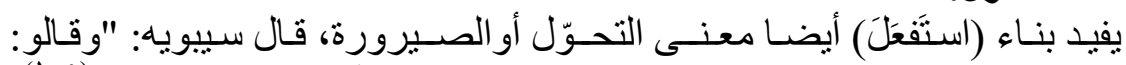

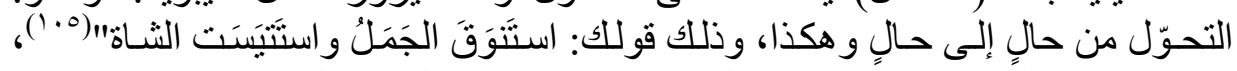

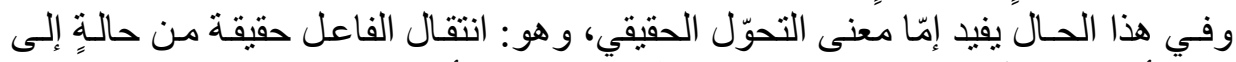

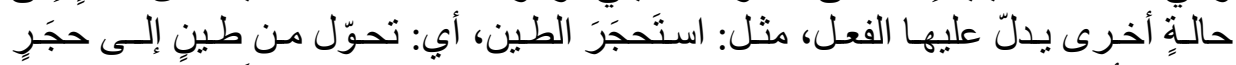

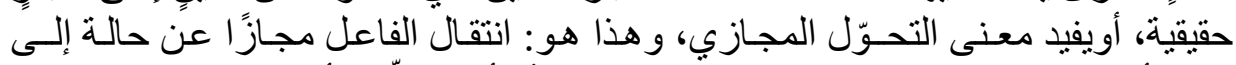

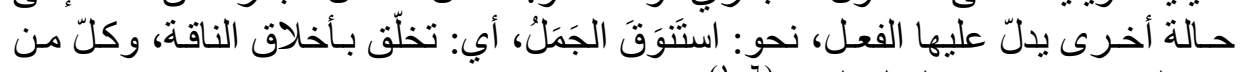

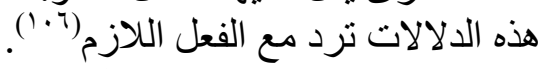
ومسن شـواهد هذه الدلالـة في الديو ان مـا ورد فـي (الدهر يومـان) حيث قـال الثافعي(') (1)

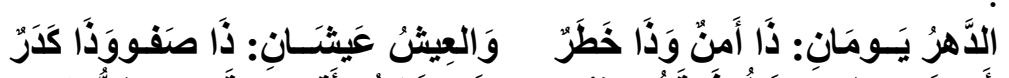

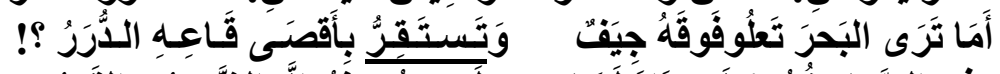

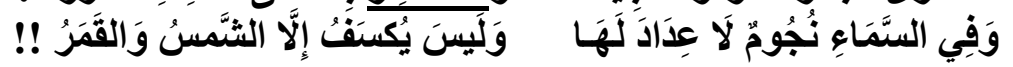

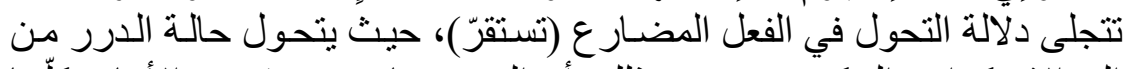

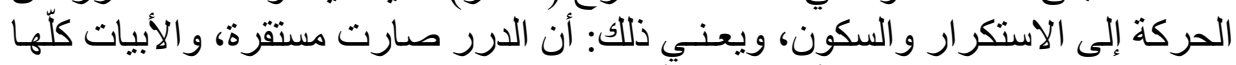

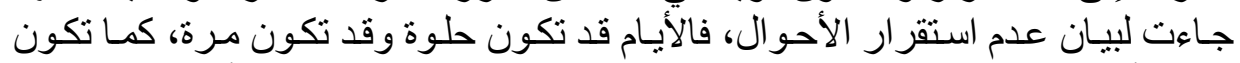

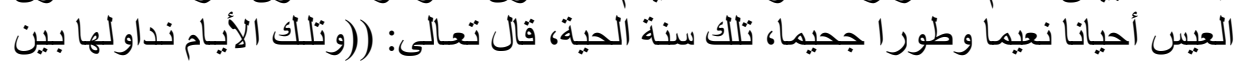

\section{الفعل المبني للمجهول ودلالاته في ديوان الثافعي}

(الناس)().

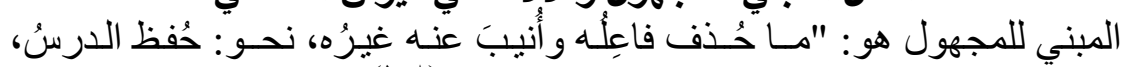

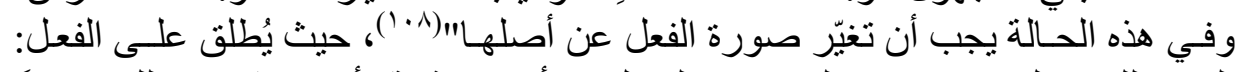

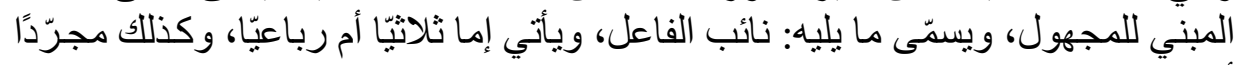

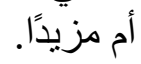
و القاعدة الأساسية في بناء الماضي للمجهول ضمّ أوّله وكسر ما قبل الآخر مثل:

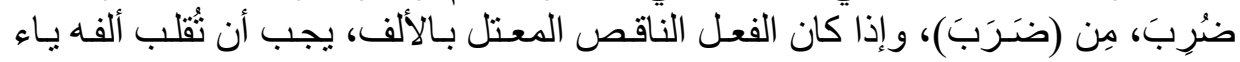

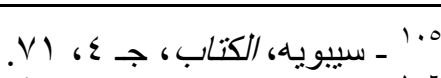

$$
\begin{aligned}
& \text { ـ الحقول الدلالية الصرفية للأفعال العربية، ص ع ع } 9 .
\end{aligned}
$$

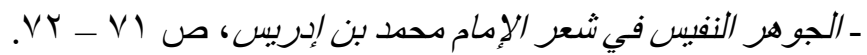

$$
\begin{aligned}
& \overline{1.0}
\end{aligned}
$$

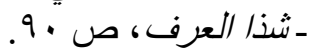




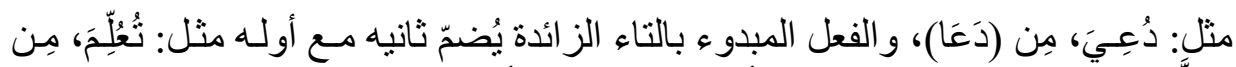

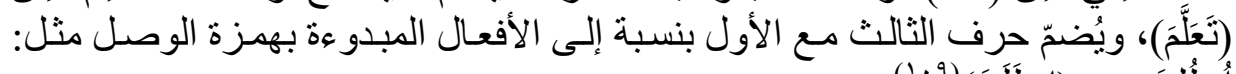

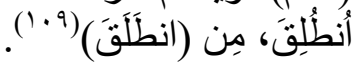

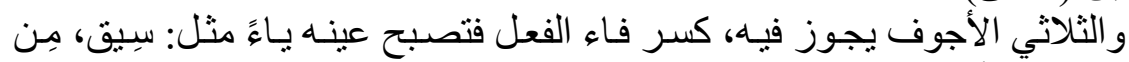

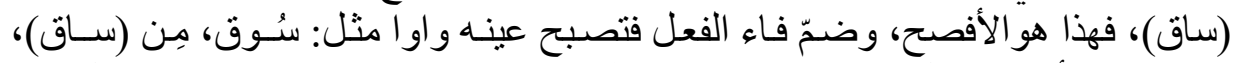

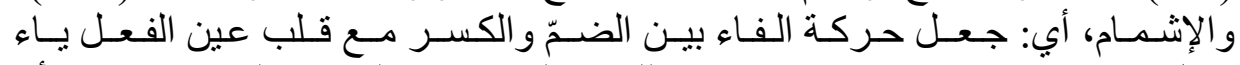

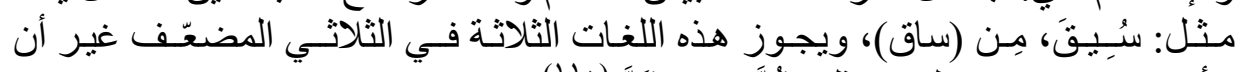

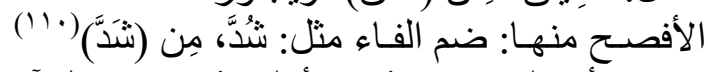

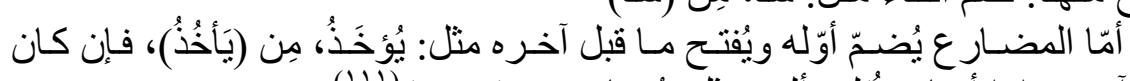

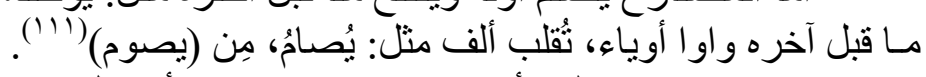

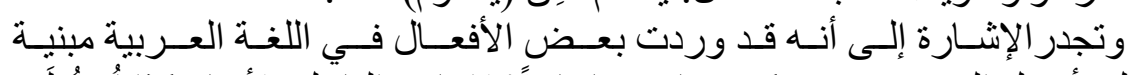

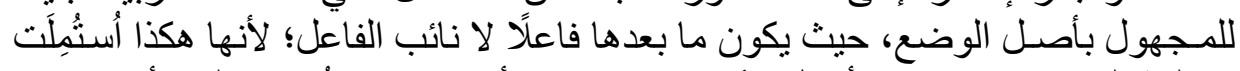

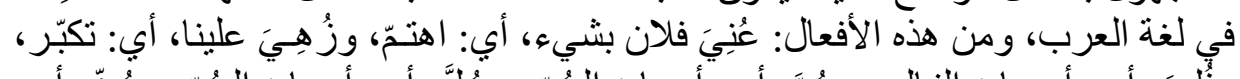

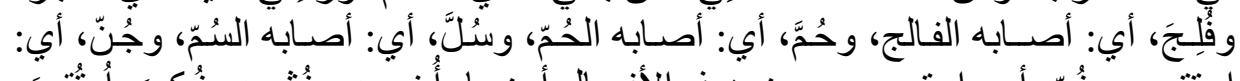

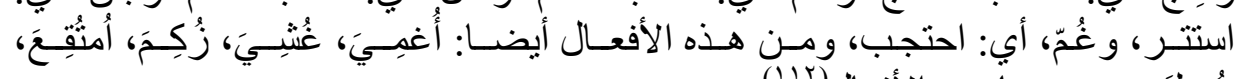

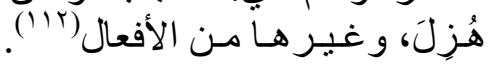

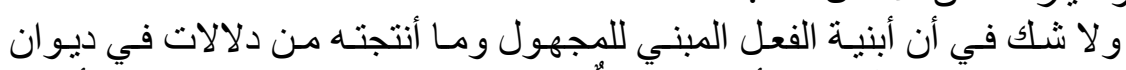

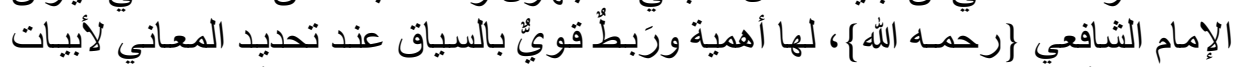

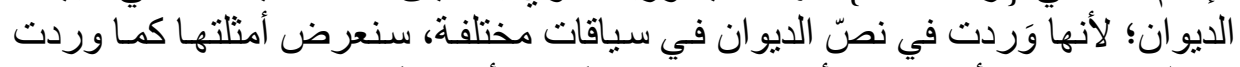

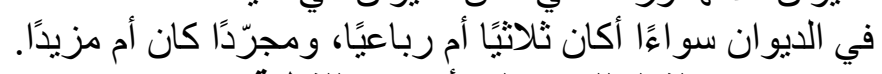

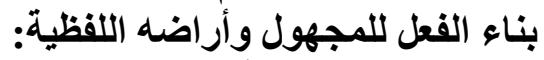

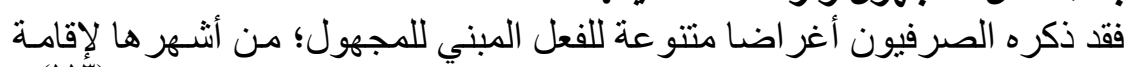

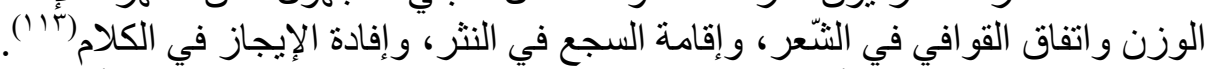

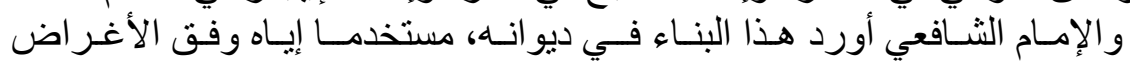

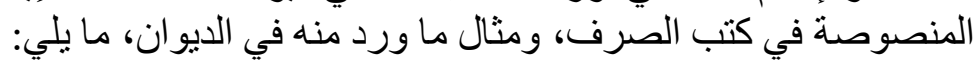

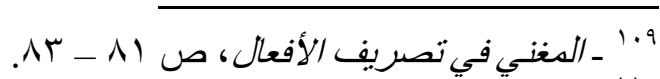

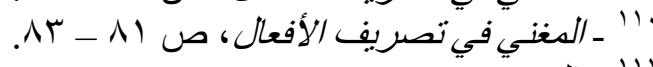

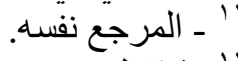

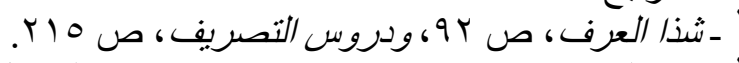

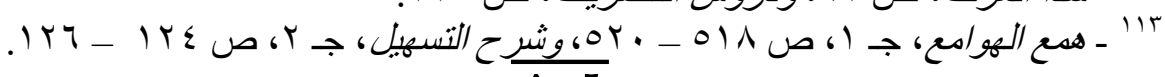




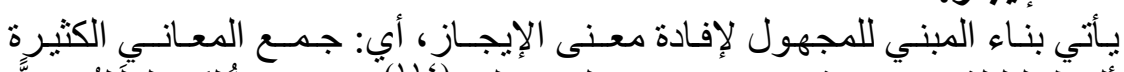

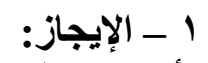

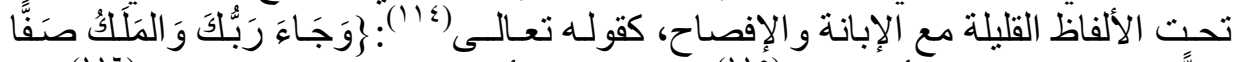

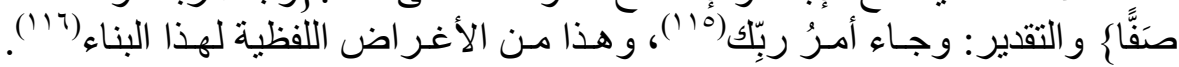

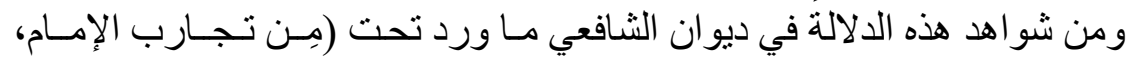

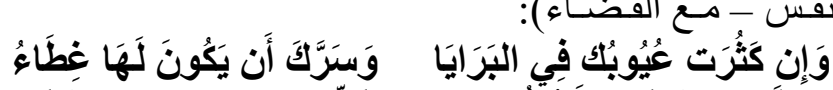

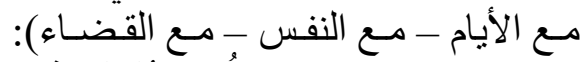

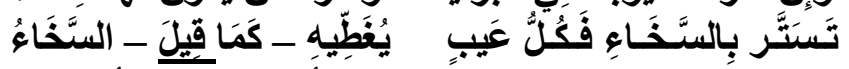

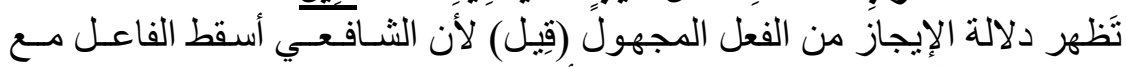

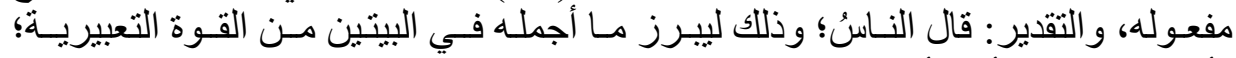
لأن الكلام يكون أثره أقوى في النفس المخاطب عندما يكون فيله إيجاز.

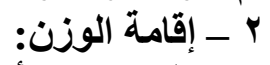

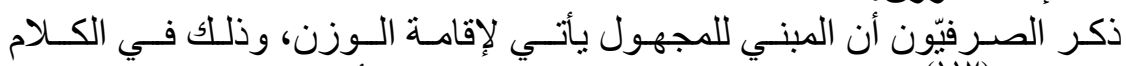

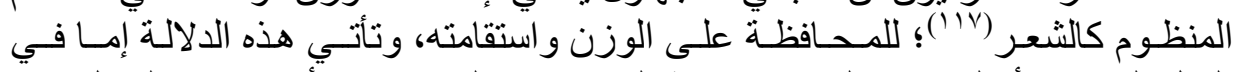

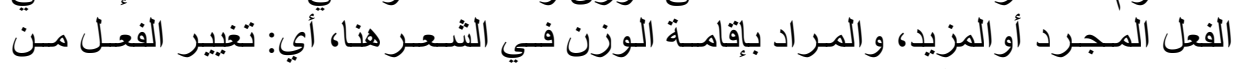

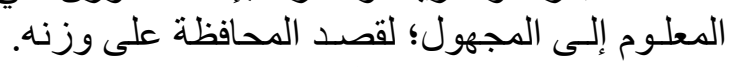
ومن شو اهد هذا الغرض مـا تضمّتنه قصيدة (ميزان التفاضل عند الثشافعي)،

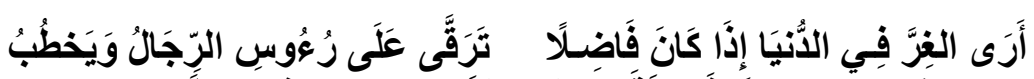

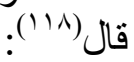

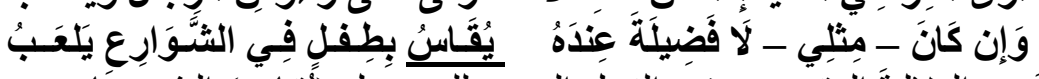

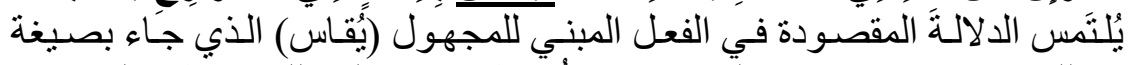

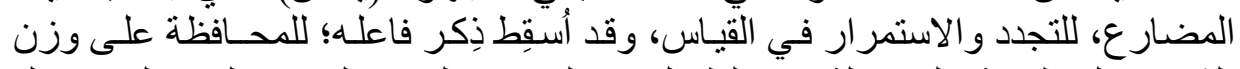

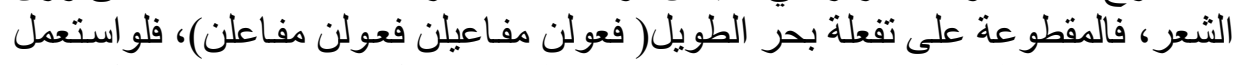

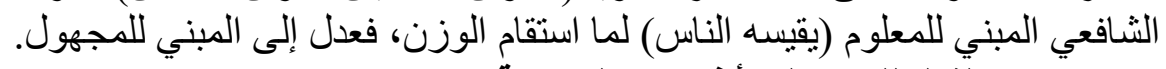
بناء الفعل للمجهول وأغراضه النهابل المعنوية:

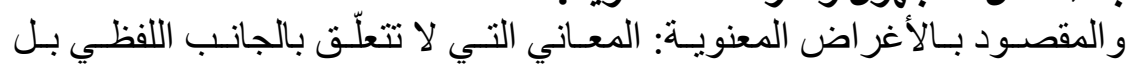

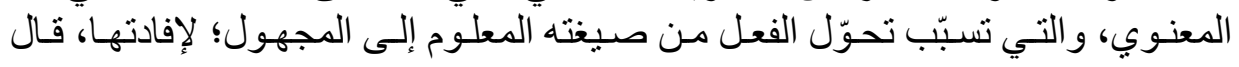

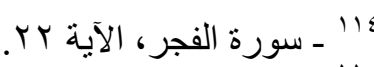

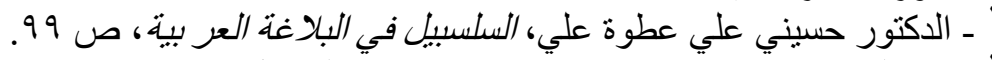

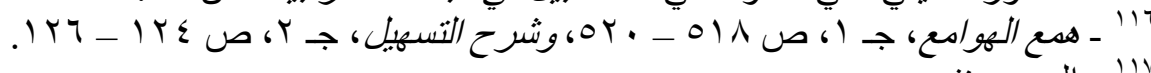

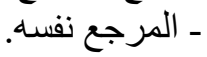

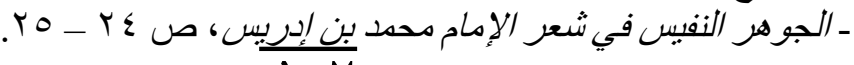




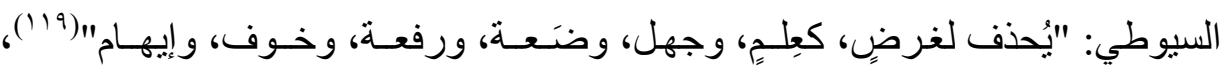

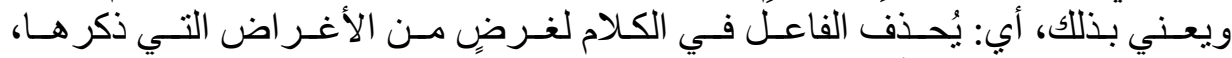

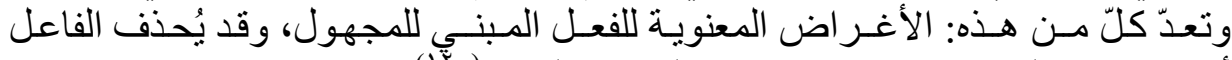

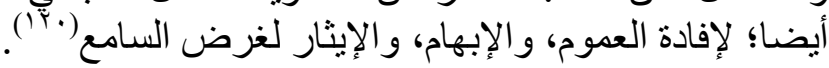

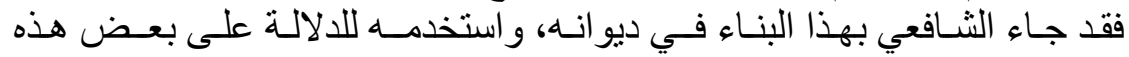
المعاني، وفيما يلي عرض لبه لبعض هذه الدلاءلات.

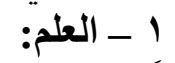

ذَكر ابن ماللك و غيره مـن الصرفيبين أن الفعل المبني للمجهول يُستعمل للالالية

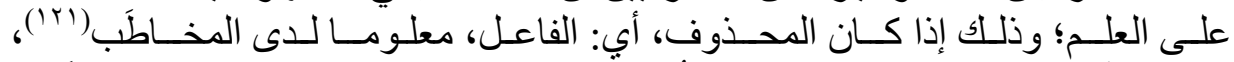

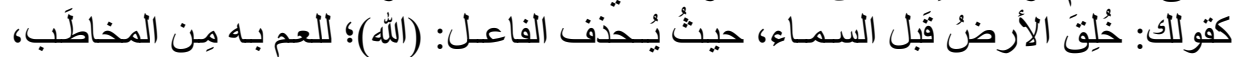

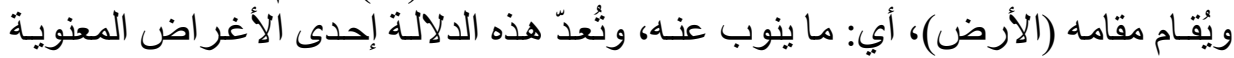
لهذا البناء.

ومن شـو اهدها - على سبيل المثال - مـا ورد في (دليل على القضـاء وحكمـه)

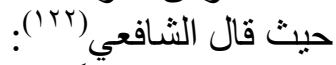

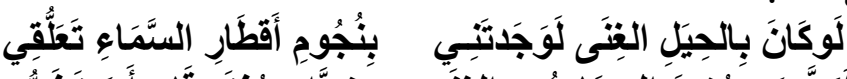

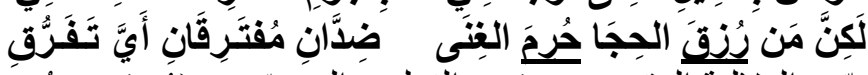

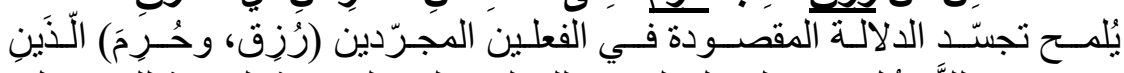

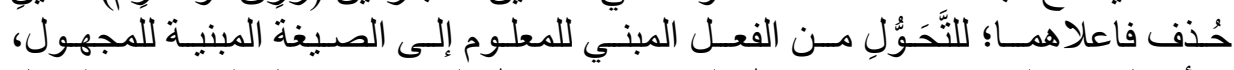

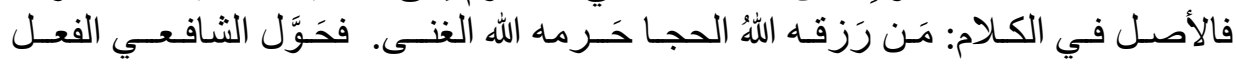

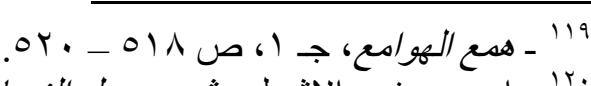

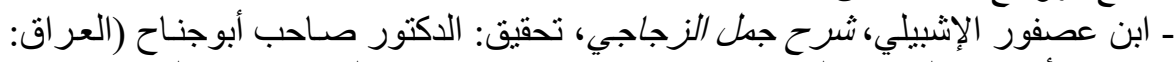

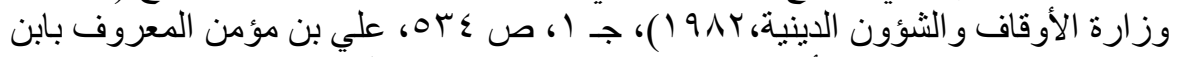

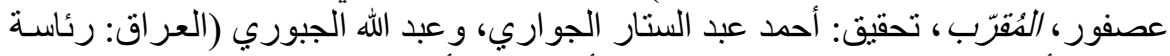

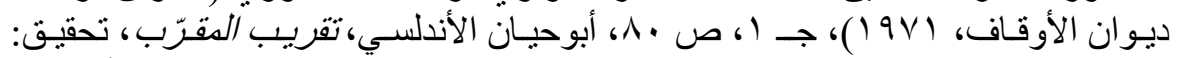

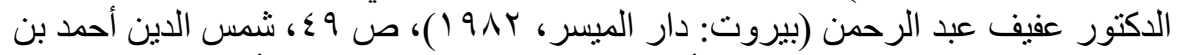

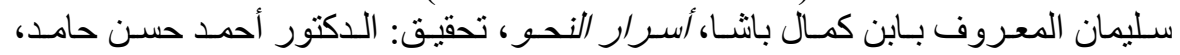

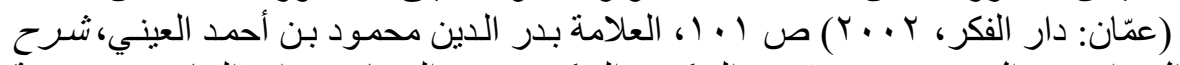

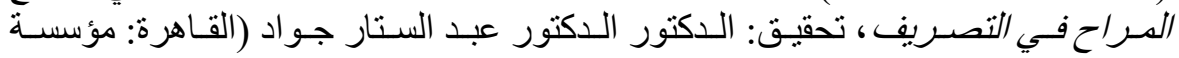

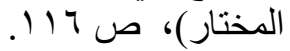

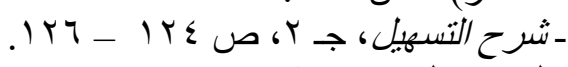

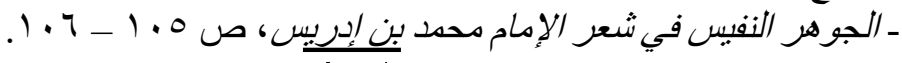


الثثلاتي المجرّد المبني للمعلوم إلىى المبني للمجهول بحذف فاعله: (الله)؛ وذلك لكونـه

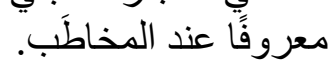
r - الجهل:

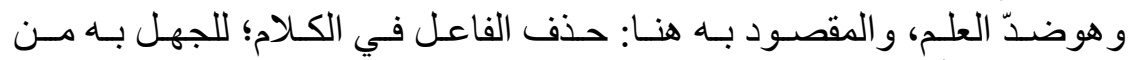

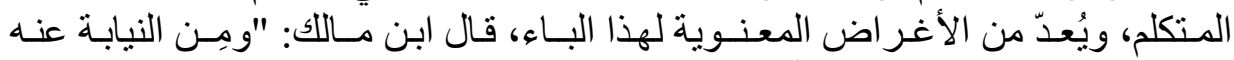

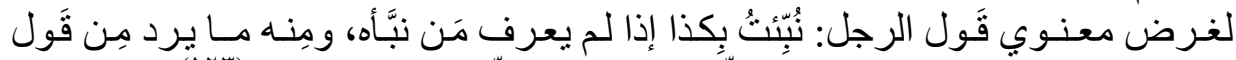

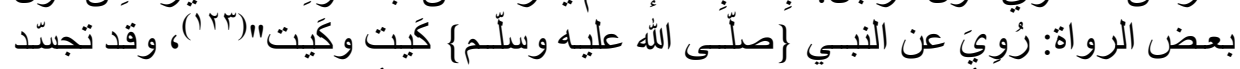

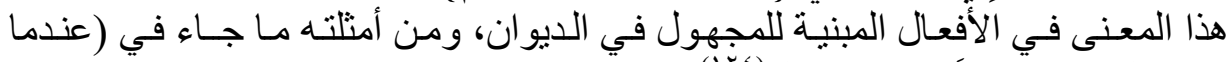

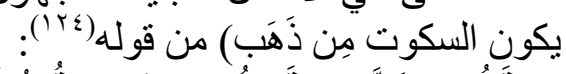

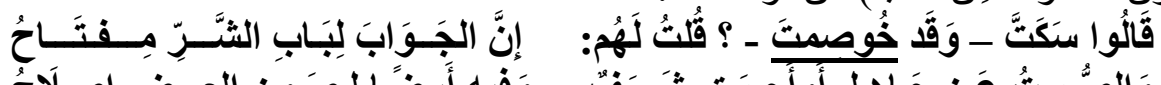

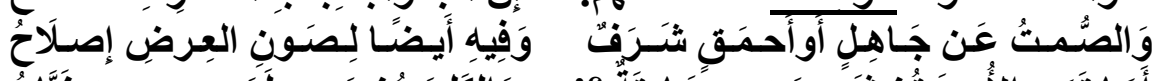

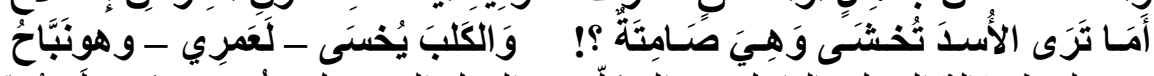

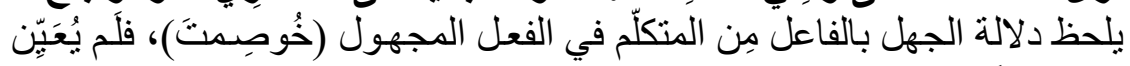

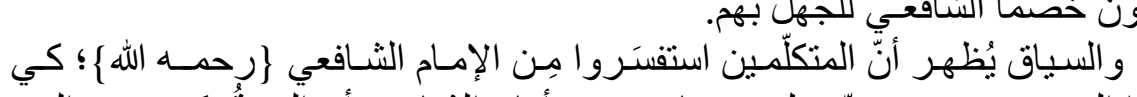

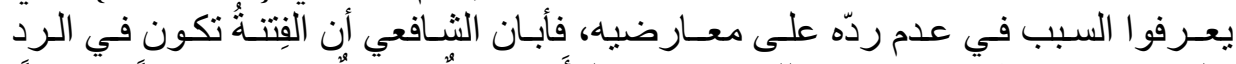

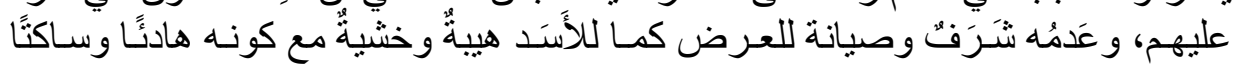
في مَسكنها. الخاتمة

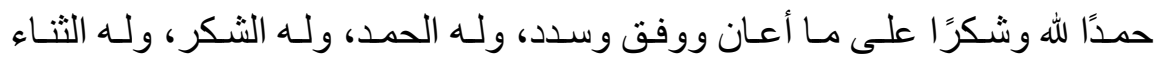

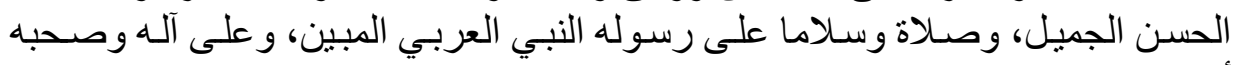

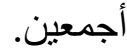

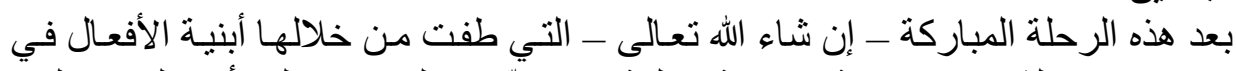

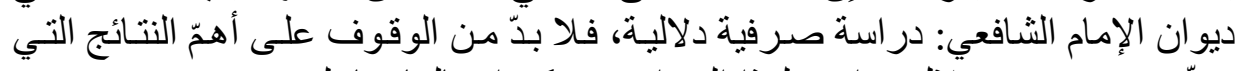

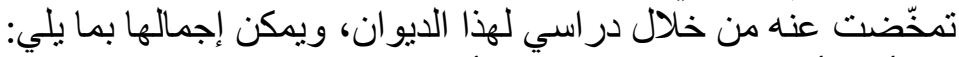

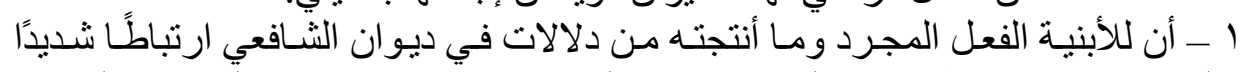

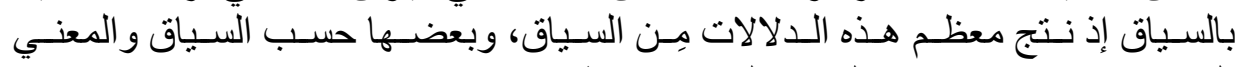
المعجمي، وبعضها حسب المعنى المعجمي فقط.

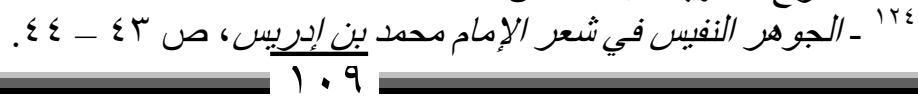




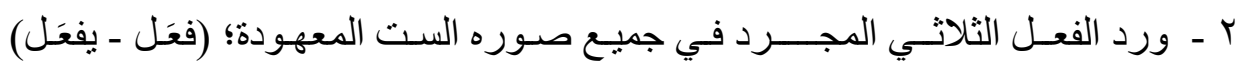

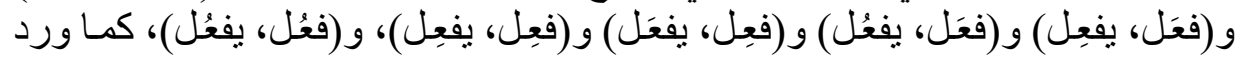

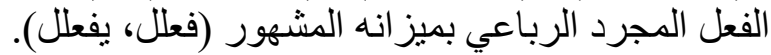

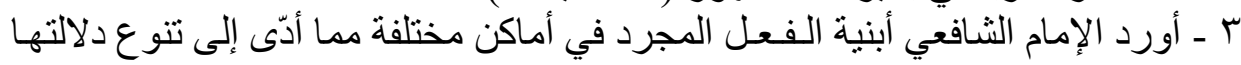

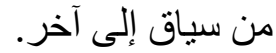

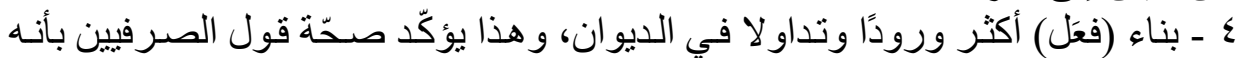

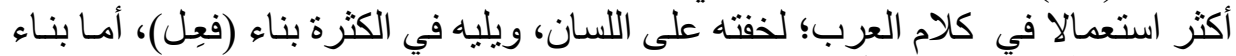

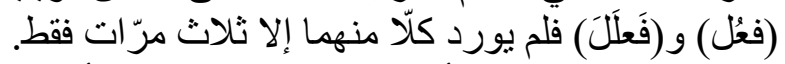

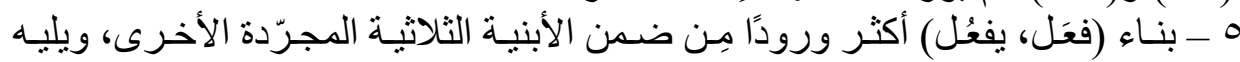

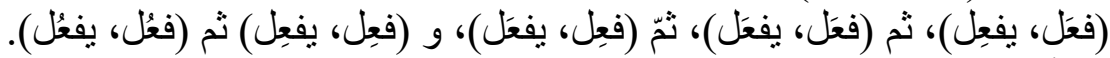

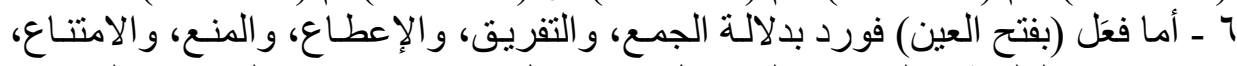

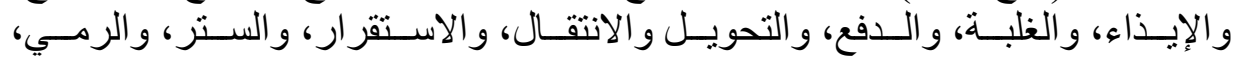

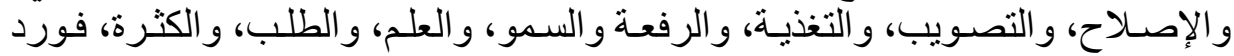

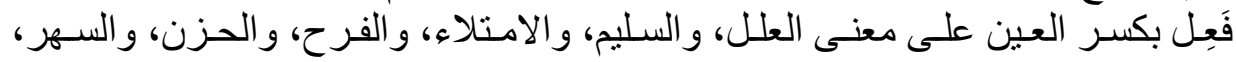

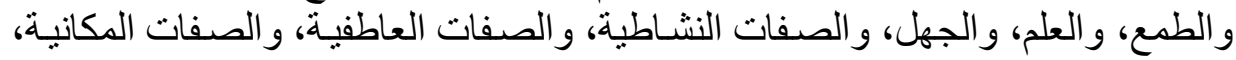

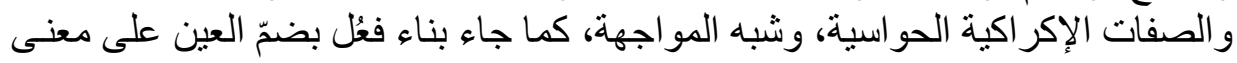

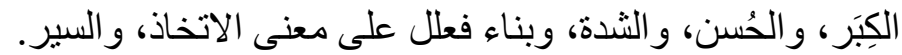

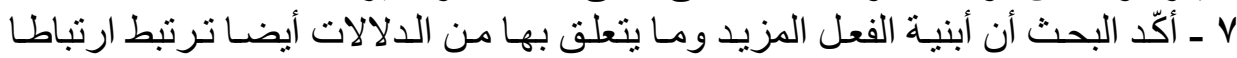

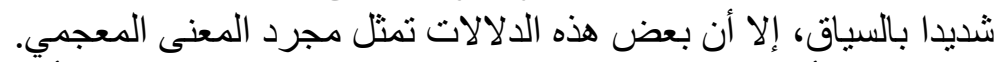

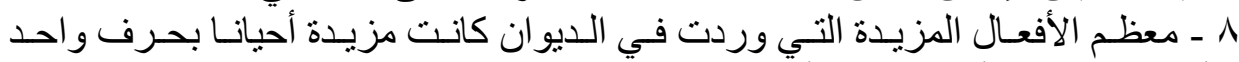

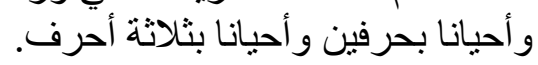

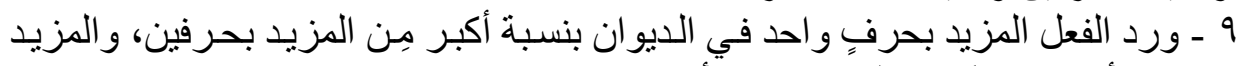

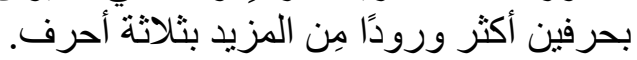

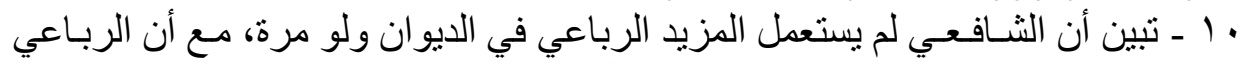

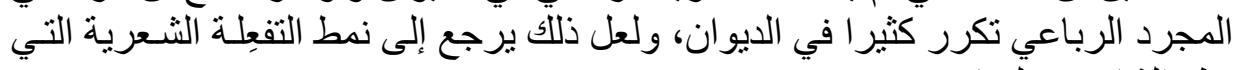
نظم الثافعي علَيها.

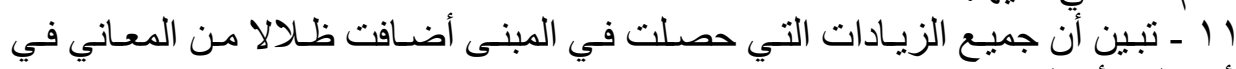

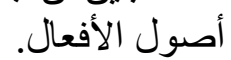

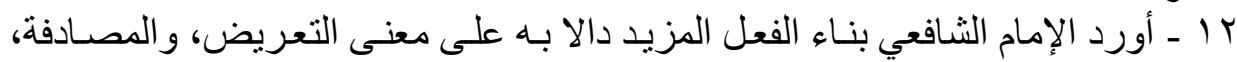

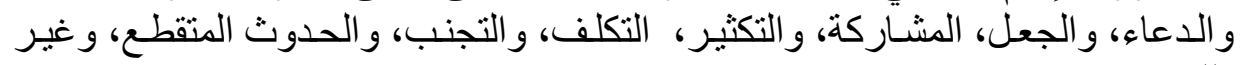
ذلك. 
سا ـ ـترتبط أبنية الفعل المبني للمجهول أيضا وما أنتجته من دلالات في الديوان ارنباطًا

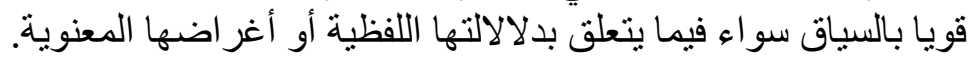

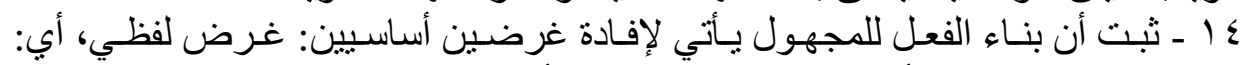

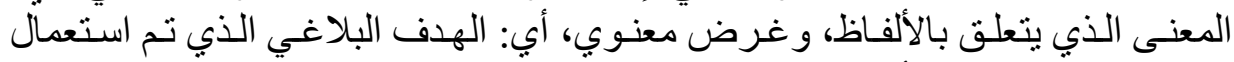
صيغة المبني للجهول لألجله الألفان.

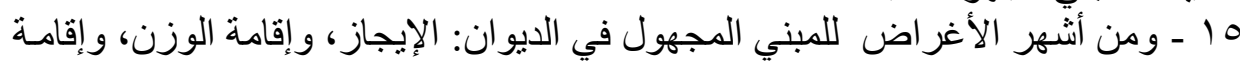

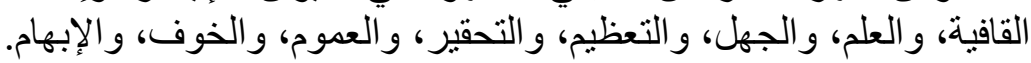


فهرس المراجع والمصادر 1 إبر إبر الهيم محمد نجا. الدعاجم اللغوية. المملكة العربية السعودية: الجامعة الإسلامية

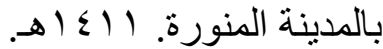
r ـ أبو إبر اهيم إسحاق بن إبر اهيم الفار ابي. ديوان الأدب. تحقيق: الدكتور أحمد مختار

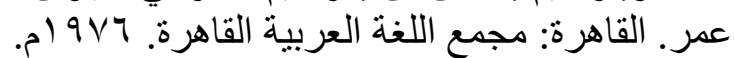

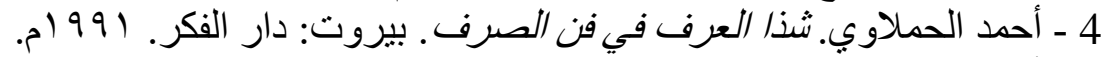

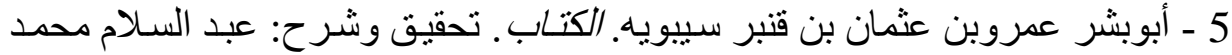
هارون. بيروت: دار الجميل.

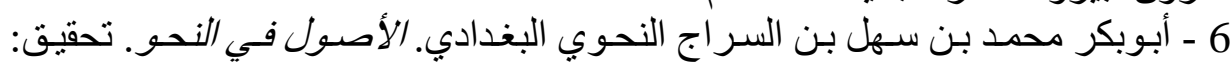
الدكتور عبد الحسين الفنلي. بيروت: مؤسئة الرسالة.

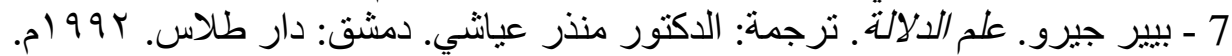

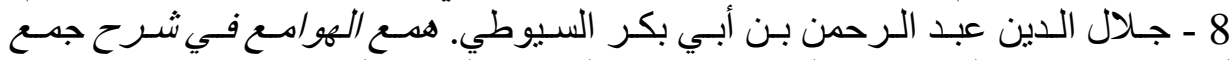

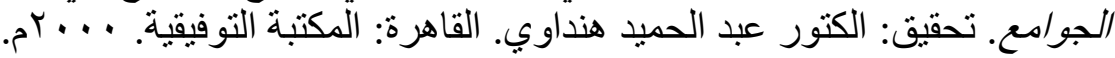

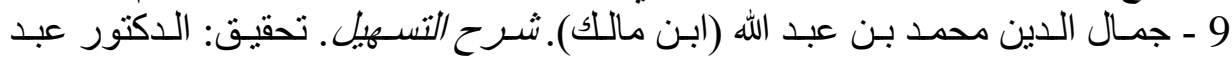
الرحمن السيد، والكتور محمد بدوي المختون. القاهرة: هجر للطباعة والنشر و التوزيع. 10- أبوحيان الأندلسي. ارتثـاف الضـرب من لسـان العرب. تحقيق وشر ح: الدكتور

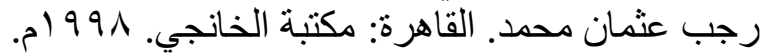
11 - أبوحيان الأندلسي. السبدع في التصريف. تحقيق الحقيق وشرح وتعليق: الكتور عبد الحميد

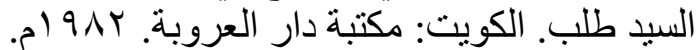
12 - أبوحيان الأندلسي.تقريب الدقرّب. تحقيق: الدكتور عفيف عبد الرحمن. بيروت:

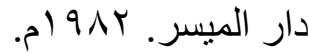
13 - حسيني علي عطوة علي. السلسبيل في البلاغة العر بية. غير منشر.

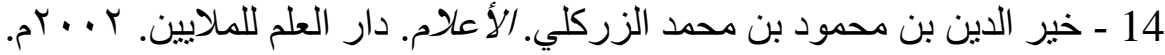

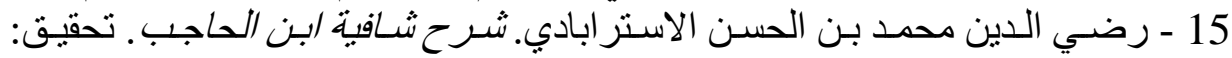

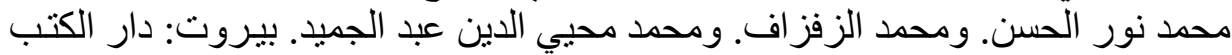
16 - سليمان فياض. الحقول الدلالـة الصـرفية للأفعال العربية. الريـاض: دار المريخ

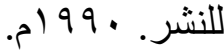
17 - شمس الدين أحمد بن سليمان المعروف بـابن كمال باثـا. أسرار النحو. تحقيق:

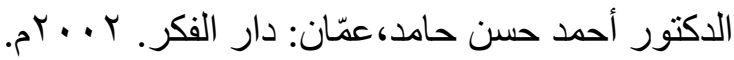


18 ـ الطيب البكّوش. التصـريف العربـي من خـلال علم الأصسوات الحـديث تـونس:

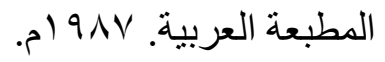

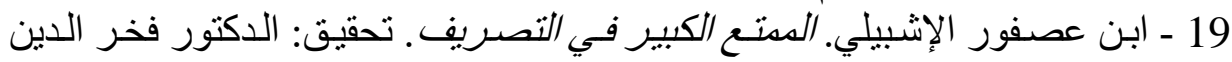
قباوة. بيروت: مكتبة لبنان ناشترون.

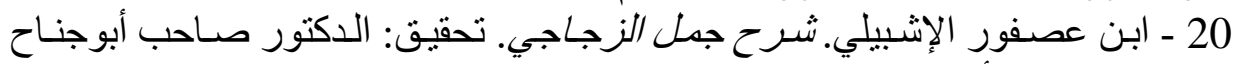

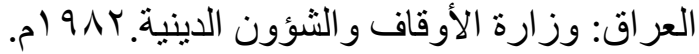

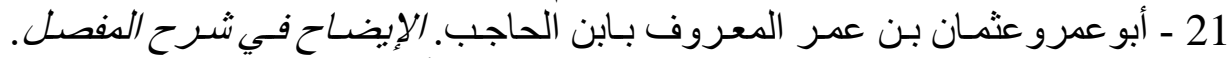

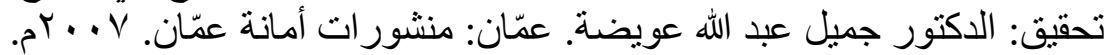

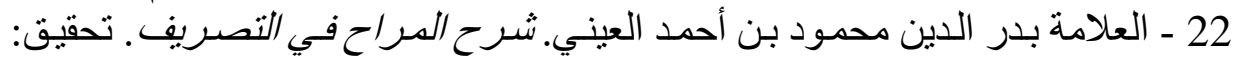

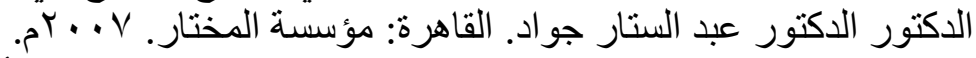

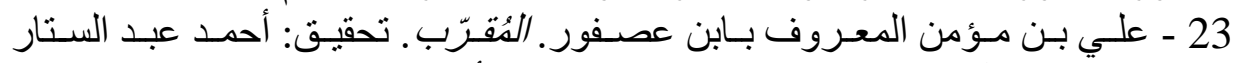

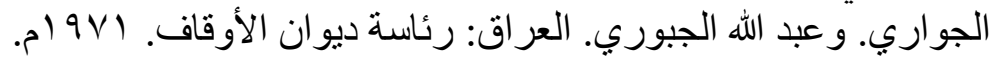

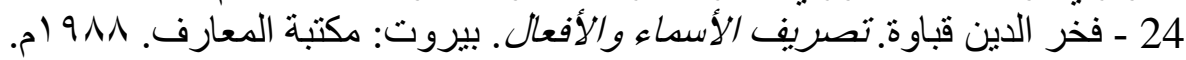

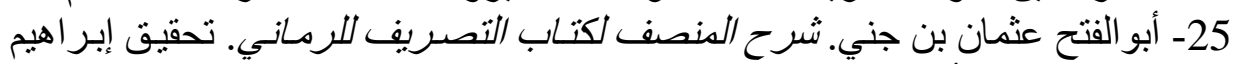

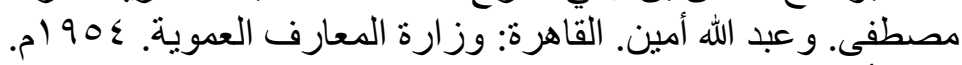

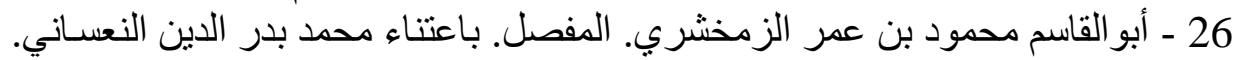
بيروت: دار الجمل. بـ 9 أم. 27 - محمد إبر اهيم سليم. الجوهو المر النفيس في شعر الإمام محمد بن إدريس. القاهرة: مكتبة ابن سينا.

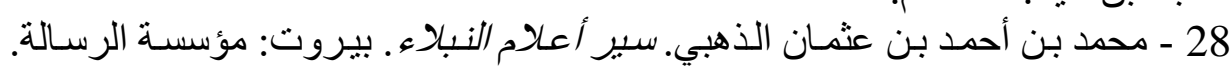
.) 997 29 - محمد عبد الخـالق عضبمة. الدغنسي فـي تصريف الأفعـال. القاهرة: دار الحديث. .p) 999 30 - محمد محيب الدين عبد الحميد. دروس التصريف. القاهرة: دار الطلاع. ه ـ . بَ. 

أبنية الأفعال في ديوان الإمام... 